\title{
The pleiotropic roles of transforming growth factor beta in homeostasis and carcinogenesis of endocrine organs
}

\author{
Markus C Fleisch*, Christopher A Maxwell ${ }^{*}$ and Mary-Helen Barcellos-Hoff
}

Life Sciences Division, 1 Cyclotron Road, MS 977-225A, Lawrence Berkeley National Laboratory, Berkeley, California 94720, USA

(Requests for offprints should be addressed to M H Barcellos-Hoff; Email: MHBarcellos-Hoff@lbl.gov)

*(M C Fleisch and C A Maxwell contributed equally to this work)

\begin{abstract}
Transforming growth factor $\beta$ (TGF- $\beta$ ) is a ubiquitous cytokine that plays a critical role in numerous pathways regulating cellular and tissue homeostasis. TGF- $\beta$ is regulated by hormones and is a primary mediator of hormone response in uterus, prostate and mammary glands. This review will address the role of TGF- $\beta$ in regulating hormone-dependent proliferation and morphogenesis. The subversion of TGF- $\beta$ regulation during the processes of carcinogenesis, with particular emphasis on its effects on genetic stability and epithelial to mesenchymal transition, will also be examined. An understanding of the multiple and complex mechanisms of TGF- $\beta$ regulation of epithelial function, and the ultimate loss of TGF- $\beta$ function during carcinogenesis, will be critical in the design of novel therapeutic interventions for endocrine-related cancers.
\end{abstract}

Endocrine-Related Cancer (2006) 13 379-400

\section{Introduction}

The members of the TGF- $\beta$ family are highly conserved in mammals and are involved in a variety of cellular functions from embryo development to adult tissue homeostasis (Herpin et al. 2004). TGF$\beta 1$, which is the founding member and often referred to as the 'prototype' of this family, was originally named based on its ability to stimulate anchorage independent growth in fibroblasts (Roberts et al. 1981). However, in many respects, transforming is a misnomer since in addition to this transforming capacity, TGF- $\beta$ stringently regulates epithelial growth control, mediates DNA damage repair, and stimulates apoptosis and stem cell function (Fig. 1). Thus, TGF- $\beta$ demonstrates both oncogenic and tumor suppressive properties (reviewed in Derynck et al. 2001). This review will highlight the functions of TGF- $\beta$ on hormonedependent epithelia ranging from the regulation of normal development and homeostasis to its role in oncogenesis and progression. Our studies using in vitro and in vivo models of mammary development and radiation-induced carcinogenesis will be used to illustrate several TGF- $\beta$ roles.

\section{TGF- $\beta$ activation}

There are three mammalian $T g f \beta$ genes $(\operatorname{Tg} f \beta 1$, $\operatorname{Tgf} \beta 2$, and $\operatorname{Tgf} \beta 3$ ), for which there is a high degree of sequence homology and some functional overlap. This review will focus on TGF- $\beta 1$. Nearly all cells secrete latent TGF- $\beta$ and express the TGF$\beta$ receptors making the restriction of TGF- $\beta$ activation a key regulator for its biological effects. Recent detailed reviews on TGF- $\beta$ activation and signaling are available (Yue \& Mulder 2001, Siegel \& Massague 2003, Rifkin 2005).

TGF- $\beta$ can act in an autocrine, paracrine or endocrine fashion (Smith 1996). All TGF- $\beta$ isoforms are secreted as inactive, or latent, forms and upon activation can potentially bind three surface receptors (T $\beta \mathrm{R}$ I-III). The ubiquitously secreted and inactive form is called 'latent complex (LTGF- $\beta$ )' and it consists of the mature TGF- $\beta$ dimer non-covalently bound to its latency associated peptide (LAP). In addition, some LTGF- $\beta$ is bound to latent TGF- $\beta$ binding protein (LTBP) (Rifkin 2005). Most cells, including epithelial, stromal, and immune cells such as macrophages, make TGF- $\beta$ and have receptors for the ligand. The secretion of 
Table 1 The pleiotropic roles of TGF- $\beta$ on homeostasis, disease and carcinogenesis within a variety of endocrine organs. Effects have been described in, but are not necessarily restricted to, the attributed organs.

\begin{tabular}{|c|c|c|c|}
\hline Organ & $\begin{array}{l}\text { Specific actions of TGF- } \beta \text { in } \\
\text { homeostasis and disease }\end{array}$ & $\begin{array}{l}\text { Role of TGF- } \beta \text { in cancer and } \\
\text { premalignant lesions }\end{array}$ & References \\
\hline Breast & $\begin{array}{l}\text { Regulates mammary gland } \\
\text { morphogenesis } \\
\text { Inhibits steroid receptor positive cell } \\
\text { proliferation at estrus } \\
\text { Orchestrates DNA damage response }\end{array}$ & $\begin{array}{l}\text { Early stage tumor inhibitor } \\
\text { Tamoxifen increases systemic } \\
\text { TGF- } \beta \text { levels } \\
\text { Promotes EMT at later stage }\end{array}$ & $\begin{array}{l}\text { Barcellos-Hoff \& Ewan (2000), Brown et al. } \\
\text { (2004), Chen et al. (1996), Derynck et al. } \\
\text { (2001), Ewan et al. (2002b, 2005) }\end{array}$ \\
\hline Prostate & $\begin{array}{l}\text { Mediates apoptosis and involution } \\
\text { after androgen withdrawal } \\
\text { Promotes ageing in the prostate and } \\
\text { induces extracellular matrix } \\
\text { remodeling } \\
\text { Maintains quiescence of stem cell } \\
\text { compartment }\end{array}$ & $\begin{array}{l}\text { Downregulation of } \mathrm{T} \beta \mathrm{RI} \text { and II } \\
\text { TGF- } \beta \text { promotes malignant } \\
\text { progression }\end{array}$ & $\begin{array}{l}\text { Kyprianou (1999), Untergasser et al. (2005) } \\
\text { Guo \& Kyprianou (1998), Salm et al. (2005) }\end{array}$ \\
\hline Thyroid & $\begin{array}{l}\text { Participates in thyroid differentiation } \\
\text { Mediates fibrosis in autoimmune } \\
\text { disease }\end{array}$ & $\begin{array}{l}\text { Inactivation of signaling cascade } \\
\text { (autonomous adenoma) } \\
\text { Smad4 is mutated and } \\
\text { deregulated by aberrant } \\
\text { splicing in tumors }\end{array}$ & $\begin{array}{l}\text { Nicolussi et al. (2003), Eszlinger et al. (2004), } \\
\text { Lazzereschi et al. (2005) }\end{array}$ \\
\hline Uterus & $\begin{array}{l}\text { Regulates both apoptosis and } \\
\text { proliferation in the endometrium } \\
\text { during pregnancy }\end{array}$ & $\begin{array}{l}\text { Overexpression of Smad7 } \\
\text { Loss of response to TGF- } \beta \text { in } \\
\text { endometrial (EM) cancer } \\
\text { T } \beta \text { RII mutations in EM cancer }\end{array}$ & $\begin{array}{l}\text { Parekh et al. (2002), Piestrzeniewicz-Ulanska } \\
\text { et al. (2002, 2003, 2004) } \\
\text { Shooner et al. (2005) }\end{array}$ \\
\hline Testes & $\begin{array}{l}\text { Spermatogenesis, Leydig cell } \\
\text { steroidogenesis, extracellular } \\
\text { matrix synthesis and testis } \\
\text { development }\end{array}$ & & Wang \& Zhao (1999) \\
\hline Ovary & Role in ovarian development & $\begin{array}{l}\text { Loss of response to TGF- } \beta \text { with } \\
\text { intact Smad signaling }\end{array}$ & Baldwin et al. (2003), Drummond (2005) \\
\hline Pancreas & $\begin{array}{l}\text { Inhibits diabetes onset by expanding } \\
\text { CD4/CD25 }+\mathrm{T} \text { cell population }\end{array}$ & $\begin{array}{l}\text { Promotes pancreatic fibrosis } \\
\text { Induces MUC-4 expression }\end{array}$ & Choudhury et al. (2000), Menke et al. (1997) \\
\hline
\end{tabular}

TGF- $\beta$ in latent forms is a principle regulatory event that restricts its biological availability and makes LTGF- $\beta$ activation the key to understanding its activity in situ.

In addition to its regulatory functions, LTBP provides a means of anchoring latent TGF- $\beta$ within the extracellular matrix (ECM) (BarcellosHoff \& Ewan 2000). Fibronectin (Fn) provides an initial scaffold that precedes and patterns LTBP-1 deposition (Dallas et al. 2005). Fn is also required for the continued assembly of LTBP1 into the ECM of osteoblasts and fibroblasts (Dallas et al. 2005). Cleavage of the LAP and the adjacent LTBP, by several proteases such as plasmin, thrombin, plasma transglutaminases and endoglycosylases, is an initial step in the activation of TGF- $\beta$ (Javelaud \& Mauviel 2004). Recent evidence demonstrates that LTBP-1 enables $\alpha \mathrm{v} \beta 6$ integrin-mediated activation by both fixing and concentrating the latent complex in the ECM leading to a mechanical stretching of the LTGF- $\beta$ molecule (Annes et al. 2004). In addition to the aforementioned mechanisms, LTGF- $\beta$ is efficiently activated by exposure to reactive oxygen species that may be generated by ionizing radiation and other sources (Barcellos-Hoff et al. 1994, BarcellosHoff 1996).

Using antibodies specific for latent and active TGF- $\beta$ we were able to show that TGF- $\beta$ activation in the mouse mammary gland is an event that is spatially and temporally highly restricted (Ewan et al. 2002a). Active TGF- $\beta$ localized predominantly to the luminal epithelium and is undetectable in myoepithelial cells and is weakly detected in normal stroma. Within the luminal epithelium during phases of proliferation (puberty, estrus or pregnancy), active TGF- $\beta 1$ is restricted to certain cells. Alterations in immunolocalization pattern, from hetero- to homogeneous, as a function of the estrous cycle suggested that TGF- $\beta$ activation in 
the mammary gland is regulated by ovarian hormones.

\section{TGF- $\beta$ signaling}

Once activation releases TGF- $\beta$ from the latent complex, it can bind to ubiquitously expressed surface receptors of target cells (Fig. 1). The type I (T $\beta R I)$ and type II (T $\beta R I I)$ TGF- $\beta$ receptors are transmembrane serine-threonine kinases while the type III receptor (T $\beta$ RIII), a membrane bound proteoglycan also known as beta-glycan, lacks kinase activity. TßRIII, which also exists in a soluble form, can covalently bind two TGF- $\beta$ molecules increasing the concentration of TGF- $\beta$ at the cell surface and maximizing the interaction with type I and II receptors (Lopez-Casillas et al. 1993). TGF- $\beta$ bound to T $\beta$ RII recruits T $\beta$ RI to execute transphosphorylation (Wrana et al. 1994). T $\beta$ RI subsequently phosphorylates receptor-regulated Smad proteins 2 and 3 (R-Smads). Smad2/3 proteins can either interact with Smad4 and translocate to the nucleus to initiate gene transcription or can interact with inhibitory Smad (I-Smads) proteins (i.e Smad7) that functionally inhibit the cascade (see below). Once within the nucleus, Smad2/3/4 forms a nuclear complex with additional cell-specific co-transcription factors. These complexes bind to and regulate the transcription of a variety of target promoters and genes, depending on the type of co-factors present (Massague \& Chen 2000). Massague and coworkers used transcriptomic profiling to show that there are groups of genes that seem to be commonly regulated after TGF- $\beta$ stimulation of three different human epithelial cell lines (HaCat skin keratinocytes, MCF-10A

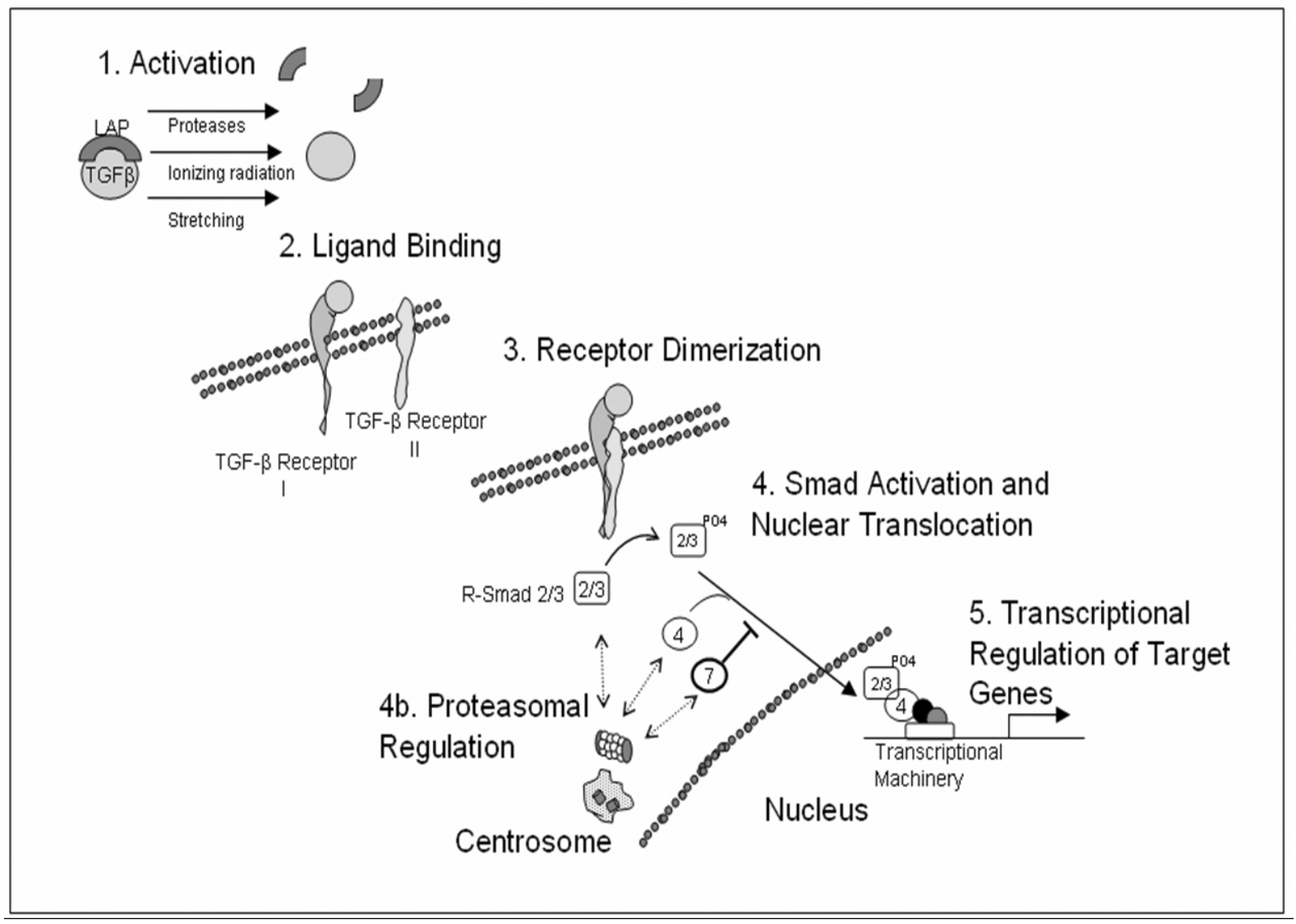

Figure 1 Canonical TGF- $\beta$ signaling pathway. As many cells express TGF- $\beta$ and its receptors, the restriction of TGF- $\beta$ activation is a key regulator of its activity. TGF- $\beta$ activation occurs through multiple mechanisms including proteases, heat, ionizing radiation and mechanical stretching. Once activated, TGF- $\beta$ binds to TGF- $\beta$ receptor I leading to dimerization with TGF- $\beta$ receptor II and activation of receptor Smad (R-Smad) complexes. Upon activation, R-Smads translocate to the nucleus and complex with the cellular transcriptional machinery to regulate gene expression. R-Smad activation and translocation is subject to proteasomal regulation and additional regulation by inhibitory-Smad complexes, including Smad7. 
breast epithelial cells and HPL1 lung epithelial cells) (Kang et al. 2003). TGF- $\beta$ stimulation regulated the expression of over 100 genes in at least two of these cell lines. Functional grouping of these genes demonstrated the broad spectrum of TGF- $\beta$ effects on epithelial cell function. Genes were clustered in groups regulating cytostatic program, extracellular matrix, paracrine network, signaling network, transcriptional network, negative feedback and other responses (Kang et al. 2003).

\section{TGF- $\beta$ signaling and proteasomal activity}

Mechanisms for feedback regulation of TGF- $\beta$ signaling are beginning to be elucidated. Members of the I-Smad subclass, Smad6 and Smad7, bind activated T $\beta R I$, prevent phosphorylation of RSmads and thus their nuclear translocation, and recruit E3-type ubiquitin ligases to the receptors complexes, ultimately leading to their degradation (Ebisawa et al. 2001, Derynck \& Zhang 2003, Shi \& Massague 2003). For instance, the E3 ligase Smad ubiquitination regulatory factor (Smurf1) targets Smads1, -4 and -5 for degradation depending on the presence of I-Smads (Zhu et al. 1999, Moren et al. 2005). Smad2 is targeted by additional E3 ligases for poly-ubiquitination and degradation (Fukuchi et al. 2001, Kuratomi et al. 2005). In contrast, Smad4 can be stabilized through monoubiquitination and sumoylation with consequent enhancement or inhibition of TGF- $\beta$ signaling (Long et al. 2003, Ohshima \& Shimotohno 2003, Liang et al. 2004). Recent evidence suggests that Smad-independent induction of E3 ligases, such as Smurf2, can act as negative feedback for TGF- $\beta$ mediated signaling (Ohashi et al. 2005). Another E3 ligase, AIP4, also inhibits TGF- $\beta$ signaling (Lallemand et al. 2005). Although AIP4 specifically targets Smad7, the mechanism for AIP4-mediated TGF- $\beta$ inhibition is presumably through stabilization of the Smad7/T $\beta$ RI complex revealing an alternate mechanism through which ubiquitination can regulate TGF- $\beta$ signaling (Lallemand et al. 2005). The preceding results demonstrate the strict interconnection between TGF- $\beta$-mediated signaling and proteasomal activity.

\section{TGF- $\beta$ regulation of cell cycle and epithelial growth control in hormone-dependent tissues}

One major target of TGF- $\beta$ signaling is cell cycle progression, specifically the G1-S transition.
Progress through the cell cycle is controlled by two families of proteins: the cyclins and the cyclindependent kinases (cdks). Transitions from early to late $\mathrm{G} 1$ phases and late $\mathrm{G} 1$ to $\mathrm{S}$ phases require the activation of cyclin $\mathrm{D} / \mathrm{cdk} 4$ and 6 and cyclin $\mathrm{E} /$ cdk2 complexes respectively (Yue \& Mulder 2001). These substrates are regulated by TGF- $\beta$ through two major mechanisms (Dupont et al. 2004): (1) by transcriptional activation of the cyclin-dependent kinase inhibitors p21 (WAF1) and p15 (INK4b) (Seoane 2004, Seoane et al. 2002) and (2) by inhibition of the growth promoting transcription factors c-MYC and Id 1-3 (Chen et al. 2002, Kang et al. 2003, Kowanetz et al. 2004). Additionally, TGF- $\beta$ regulates p53 activation (Ewan et al. 2002b). Active p53 induces p21, which inhibits the cyclin E/cdk2 complex and, together with $\mathrm{p} 15$, the cyclin $\mathrm{D} / \mathrm{cdk} 4$ complex. Inhibition of cyclin $\mathrm{D} / \mathrm{cdk} 4$ complexes prevents the hyperphosphorylation of retinoblastoma $(\mathrm{Rb})$ protein and thereby G1-S phase transition, resulting in a G1 arrest.

We have examined the growth suppressive effect(s) of TGF- $\beta$ at the tissue level in the mammary gland. In the normal mammary gland, TGF- $\beta$ activation is restricted to the luminal epithelium. Immunofluorescence studies in tissue sections demonstrated differential activation of TGF- $\beta$ within cellular subpopulations during phases of hormonal stimulation at estrus and pregnancy (Ewan et al. 2002a). Depletion of TGF- $\beta$, as measured in mice engineered to lack a copy of the $T g f \beta 1$ gene, results in accelerated morphogenesis during puberty and increased epithelial proliferation during estrus and pregnancy. TGF- $\beta 1$ has also been implicated in the proliferative response of breast cancer cells to steroid hormones (Wakefield et al. 1991). Depletion of TGF- $\beta$ alone, without the influence of steroid hormones (e.g. after ovariectomy), was not sufficient to increase proliferation, suggesting a role for TGF- $\beta$ in inhibiting the proliferation of steroid-sensitive cells during phases of hormonal stimulation.

Further characterization of this subpopulation of cells indicated a primary role for TGF- $\beta 1$ in the estrogen response. Approximately $35 \%$ of cells showed TGF- $\beta 1$ activation at estrus and co-localized with nuclear localization of $\operatorname{Smad} 2 / 3$, indicating autocrine action. Furthermore, nuclear $\operatorname{Smad} 2 / 3$ colocalized with nuclear estrogen receptor $\alpha(\mathrm{ER} \alpha)$ (Fig. 2). In contrast to the uterus, mammary ER $\alpha$ positive cells rarely co-localize with markers of proliferation (i.e. Ki67) in either human (Clarke et al. 1997) or rodent mammary gland (Russo 

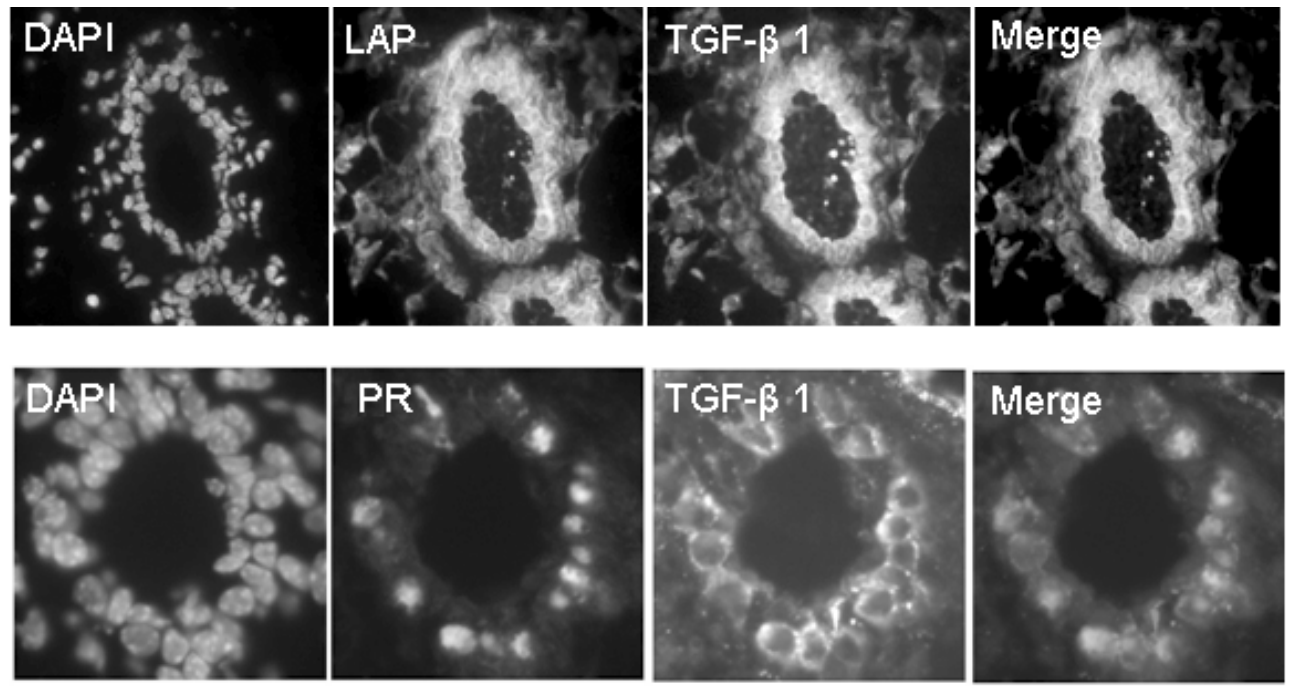

Figure 2 Dual immunofluorescence of TGF- $\beta$ activation and hormone receptor expression at estrus in the mouse mammary gland; nuclei are counter-stained with DAPI. (Upper panel) Tissue sections of mouse mammary gland at estrus are stained with antibodies specifically recognizing latent TGF- $\beta$ (LAP) and active TGF- $\beta 1$. TGF- $\beta$ activation at estrus is restricted to a subset of epithelial cells (merged image). (Lower panel) Dual staining with an antibody recognizing progesterone receptor (PR) reveals that TGF- $\beta$ activation is restricted to the PR/ER-positive cell population during estrus (merged image).

et al. 1999). To determine whether TGF- $\beta 1$ is responsible for the quiescence of the ER $\alpha$-positive population, we examined mouse mammary epithelial glands at estrus. Decreasing gene dose of TGF- $\beta$ (i.e. TGF- $\beta$ heterozygous) significantly increased $\mathrm{ER} \alpha$ co-localization with markers of proliferation (i.e. Ki-67 or 5-bromo-2-deoxyuridine $(\mathrm{BrdU}))$ at estrus. Conversely, mammary epithelial expression of constitutively active TGF- $\beta 1$, via the mouse mammary tumor virus (MMTV) promoter, suppressed proliferation of ER $\alpha$-positive cells (Ewan et al. 2005).

These results suggest a possible explanation for the changes in $E R \alpha$ frequency within human mammary breast and their relationship to breast cancer risk. Several authors have suggested that misregulation of the $\mathrm{ER} \alpha$ proliferative population may contribute to the genesis of breast cancer (Shoker et al. 1999, Frech et al. 2005). Furthermore, the frequency of ER $\alpha$ cells in human breast increase with age and other factors that correlated with breast cancer risk (Khan et al. 1994, Lawson et al. 1999, 2002). Thus, if TGF- $\beta$ regulation of the ER $\alpha$ subpopulation is a key component of mammary homeostasis, dysregulation of TGF- $\beta$ could expand the $E R \alpha$ subpopulation. Taken together, these results demonstrate that TGF- $\beta 1$ activation functionally restrains $E R \alpha$-positive cells from proliferating in the adult mammary gland. In a recent paper $\mathrm{Wu}$ et al. (2003) identified Smad4 as an $E R \alpha$ co-repressor providing a mechanism for the crosstalk between TGF- $\beta$ and estrogen. We propose that TGF- $\beta$ deregulation during ageing may promote the proliferation of $E R \alpha-$ positive cells associated with breast cancer risk in humans.

A different example for the interplay between TGF- $\beta$ and steroid hormone effects can be found in the prostate. Androgens are required in the prostate epithelium to promote growth and development (Danielpour 2005). Androgen withdrawal on the other hand leads to a dramatic apoptotic cell death (English et al. 1987) accompanied by an upregulation of TGF- $\beta$ ligands, receptors and the activation of Smads in the involuting tissue (Kyprianou \& Isaacs 1989, Kyprianou et al. 1991, Kim et al. 1996). This apoptotic response can be provoked in rats by implanting TGF- $\beta$ pellets into the prostate gland (Martikainen et al. 1990). In homeostasis there is a delicate balance between the growth promoting effects of androgens and the apoptotic effects of TGF- $\beta$. During human prostate carcinogenesis epithelial cells develop a resistance to TGF- $\beta$-mediated growth inhibition, which is paralleled by a down-regulation of T $\beta R I$ and II (Guo et al. 1997). TGF- $\beta$ exerts its effects not only directly on the epithelial compartment but also indirectly through mediating the interaction of prostate epithelial cells and the surrounding stroma. 
The physiological role of TGF- $\beta$ is less well characterized in the human endometrium, which undergoes cyclic proliferation under the influence of steroid hormones. The expression of TGF- $\beta$ in the endometrium through the menstrual and estrous cycles and pregnancy has been investigated in only a few studies. However, there is no sufficient information available on the cell-specific and temporal activation pattern of the TGF- $\beta$ isoforms (Godkin \& Dore 1998). As in other tissues, TGF- $\beta$ seems to be involved in growth regulation and at least the reported expression levels in endometrial epithelium and stroma show an estrous/menstrual cycle-dependent and therefore hormone-dependent pattern (Gold et al. 1994, Marshburn et al. 1994).

\section{TGF- $\beta$ and tamoxifen}

Tamoxifen (Tam) is a selective estrogen receptor modulator (SERM) and the current standard adjuvant treatment for ER-positive breast cancers. By inhibiting the binding of estrogen to its receptor, Tam has been shown to improve diseasefree and overall survival of patients with initial positive hormone receptor status. Tam exercises its effects by inhibiting proliferation and increasing apoptosis. A major drawback in Tam treatment is that a considerable number of patients relapse due to the development of Tam resistance. The exact mechanisms are poorly understood, but overexpression of TGF- $\beta$ has been implicated in this phenomenon (Thompson et al. 1991).

The administration of Tam itself has been shown to produce increased systemic and local levels of TGF- $\beta$. Using an MCF-7 ER-positive breast cancer cell line, Chen and colleagues showed that incubation with Tam inhibited cellular growth, induced apoptosis, up-regulated TGF- $\beta$ mRNA and activated TGF- $\beta$ (Chen et al. 1996). Moreover, inhibition of TGF- $\beta 2$, using antisense oligonucleotides, restored Tam sensitivity in an antiestrogen resistant human breast cancer cell (LCC2) (Arteaga et al. 1999). Thus, Tam induced over-expression of TGF- $\beta \mathrm{s}$, and a constitutional over-expression of TGF- $\beta$ by the progressing tumor can synergistically contribute to Tam resistance. On the other hand, the growth inhibitory effect of Tam is not completely abrogated after transfection of a dominant negative T $\beta$ RII into MCF-7 cells, showing that TGF- $\beta$ is not the exclusive mediator of Tam action (Koli et al. 1997).

\section{TGF- $\beta$ in mammary development}

TGF- $\beta$ is involved in embryogenesis, establishment of the embryonic axis, inducing meso- and endoderm, patterning the nervous system and determining the left/right asymmetry in vertebrates (for overview see Schier 2003). The murine mammary gland development is an excellent model for TGF- $\beta$-mediated regulation of epithelial growth and differentiation (for review see Barcellos-Hoff \& Ewan 2000). Under the hormonal effects of puberty (from 3-8 weeks of age in mice) the mammary tree is established in the mouse mammary fat pad. A multicellular functional unit, termed the 'end bud', is present at the tip of every developing duct. An outer layer of so-called cap cells invades the fat pad whereas cells in the center of the end bud apoptose forming a luminal structure. Once ductal development is complete, repeated estrous cycles elicit further elaboration, countered by minor involution, of the epithelium generating small lateral branches. The upsurge of hormones during pregnancy induces a massive lobuloalveolar differentiation of the epithelium increasing the epithelial cell mass from about $10 \%$ in the gland of nulliparous animals to as much as $90 \%$ in the gland of pregnant animals. Upon weaning, involution destroys the majority of the secretory units allowing the gland repeated cycles of growth and differentiation.

The contributions of TGF- $\beta$ to these processes have been investigated through experimentation with exogenous TGF- $\beta$ stimulation or preincubation with TGF- $\beta$ neutralizing antibodies, as well as within transgenic mice with manipulated levels of TGF- $\beta$. Daniel and colleagues showed that exogenous administration of TGF- $\beta$ during puberty leads to a reversible regression of end buds (Daniel et al. 1989). Interestingly, a similar protocol during pregnancy-induced growth did not impede alveolar morphogenesis (Daniel et al. 1989). If constitutively active TGF- $\beta$ is expressed under the MMTV-promoter, the gland is transiently hypoplastic during ductal morphogenesis but recovers and is able to undergo full lactational differentiation (Pierce et al. 1993). If constitutively active TGF- $\beta$ is expressed under the whey acidic protein (WAP)-promoter, a milk protein expressed during pregnancy and lactation, alveolar development is compromised but ductal morphogenesis is unaffected (Jhappan et al. 1993). These two mouse models, using developmentally restricted promoters, illustrate that TGF- $\beta$ inhibits proliferation in 
response to either the hormones of puberty or pregnancy. $\operatorname{Tg} f \beta 1$ heterozygote mice, in which TGF- $\beta$ levels are reduced by $90 \%$, show accelerated ductal outgrowth during puberty and alveolar expansion during pregnancy but have a grossly normal phenotype in the adult gland (Ewan et al. $2002 a$ ). The frequency of proliferating epithelial cells is significantly higher in $T g f \beta 1$ heterozygote mice than in wild-type mice, as also occurs in other epithelial organs such as the liver (Böttinger et al. 1997), but appears to be compensated for by increased apoptosis.

Cheng and colleagues have conditionally knocked out T $\beta$ RII selectively in mouse fibroblasts (Cheng et al. 2005). Interestingly, the mice showed a significant phenotype at 6 weeks of age with reduced ductal elongation and end bud size. Thirty percent of animals exhibited mammary gland tissue devoid of mature ducts and terminal end buds. This study showed that a loss of TGF- $\beta$ signaling in the stroma altered paracrine signaling to the mammary epithelium (Cheng et al. 2005) and thereby impaired normal mammary gland development.

\section{TGF- $\beta$ and mammary stem cells}

Transplantation experiments performed by DeOme in the 1950s were the first evidence for the existence of tissue-specific mammary epithelial stem cells (DeOme et al. 1959). These studies demonstrated that a complete and functional mammary gland could be regenerated by transplantation of small fragments from virtually every part of the donor gland. As established in hematopoietic stem cell research, the regeneration of a functional organ after transplantation has been the gold standard for demonstrating the existence of cells with stem cell self-renewal and differentiation capacity. The biology of the mouse mammary gland provides the opportunity to perform transplantation experiments without the interference of the host epithelium since the mammary gland tree develops from a glandular rudiment that can be removed before puberty and growth begins around 3 weeks of age. This results in a gland free, referred to as a 'cleared', mammary fat pad (CFP) suitable for receiving the donor tissue at the time of clearing or later. The transplantation of mammary fragments results in outgrowths that resemble the normal mammary gland morphology and function. Using the CFP technique, Sakakura (1983) showed that the morphogenesis by epithelial cells is a function of the supporting stroma. When salivary epithelium is transplanted to the mammary stroma, it exhibits the simple ductal branching pattern of mammary epithelium; conversely, mammary epithelium combined with salivary mesenchyme generates the complex pattern typical of salivary gland.

A number of studies have been conducted to determine the effects of TGF- $\beta$ on mammary epithelial stem cell function (Robinson et al. 1991, Kordon et al. 1995, Boulanger \& Smith 2001, Buggiano et al. 2001). Consistent with its general growth inhibitory function, ectopic expression of constitutively active TGF- $\beta 1$ under the WAP promoter was shown to lead to premature senescence of the mammary stem cell population as shown by a decrease in serial transplantation capacity and failure of the gland to transform into a lactating phenotype (Boulanger \& Smith 2001). The potential for TGF$\beta$-mediated premature aging of mammary stem cells led to investigations into the putative therapeutic benefits of targeting tumor stem cell-like compartments with TGF- $\beta$. Boulanger \& Smith (2001) injected the breast cancer inducing MMTV in both wild-type mice and those over expressing constitutively active TGF- $\beta$ under the WAP promoter. Only 1 of 17 animals in the TGF- $\beta$ group compared with 15 of 29 wild-type animals developed tumors in the 18 months after injection. These results infer a positive correlation between the lifespan of the mammary stem cell and cancer risk and a supervisory and inhibitory role for TGF- $\beta$ over both. The extent to which TGF- $\beta$ influences mammary stem cell functions beyond the inhibition of proliferation (which is not specific to stem cells) has so far not been investigated but is an interesting subject for future investigations.

A recent publication from Wilson's group provides further insight into the regulating effects of TGF- $\beta$ on stem cells. Prostatic stem cells are located in the mostly quiescent proximal region of the prostate gland (Tsujimura et al. 2002). Cells in this region also frequently over-express BCL-2, which protects them from apoptosis. Immunostaining for latent and active TGF- $\beta$ showed that TGF- $\beta$ activation was differential along the different parts of the prostate gland (Salm et al. 2005). In homeostasis, the cells in the proximal 'stem cell' region produced and activated significantly more TGF- $\beta$ than cells in the distal part. Androgen withdrawal resulted in an increase in distal TGF- $\beta$ activation, which led to apoptosis of cells in this region. At the same time, the proximal cells decreased TGF- $\beta$ signaling allowing stem cells to 
proliferate in response to growth factors. In addition, proximal cells were more resistant to the differentiation inducing effects of TGF- $\beta$ than the remaining cells (Salm et al. 2005).

Recently, the implications of stem cells for tumorigenesis have invigorated investigations into this theoretical cellular compartment (Reya et al. 2001). The line of argument is that a stem cell might be a target for carcinogenesis because it is long-lived, can easily accumulate damage, and might be able to conserve damage because of its slow cyclic pattern. The group of Max Wicha and Michael Clarke recently showed that a restricted subset of human breast cancer cells, defined by a combination of surface markers, has the ability to generate tumors in nude mice (Al-Hajj et al. 2003). As these cells show the generally postulated stem cell features of self-renewal and production of phenotypically heterogeneous progeny, they concluded that such cells might be considered tumor stem cells. However, the identification of their possible origin from tissue-specific stem cells has not been made due to the lack of suitable markers for the identification of normal epithelial stem cells.

\section{TGF- $\beta$ and its dual role in cancer}

Due to its growth suppressive and apoptotic effects within many non-transformed epithelial lines, TGF- $\beta$ is considered a tumor suppressor during the initial stages of carcinogenesis (Roberts \& Wakefield 2003, Siegel \& Massague 2003). The physiological activities of TGF- $\beta$ in mediating growth regulation, DNA damage responses, apoptosis, as well as the maintenance of tissue integrity and chromosomal stability may explain aspects of its tumor suppressive roles (Glick et al. 1996) (Fig. 3A). At later stages of carcinogenesis,
A.

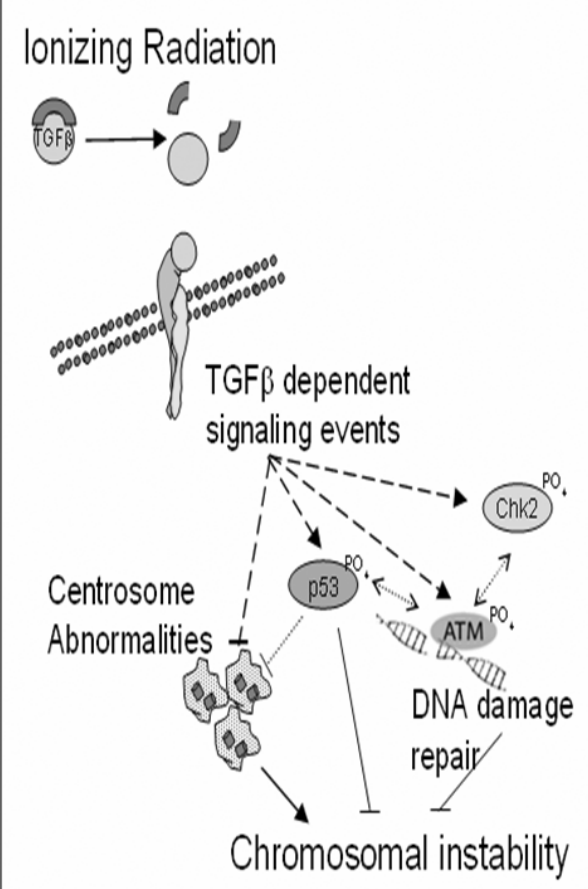

B.

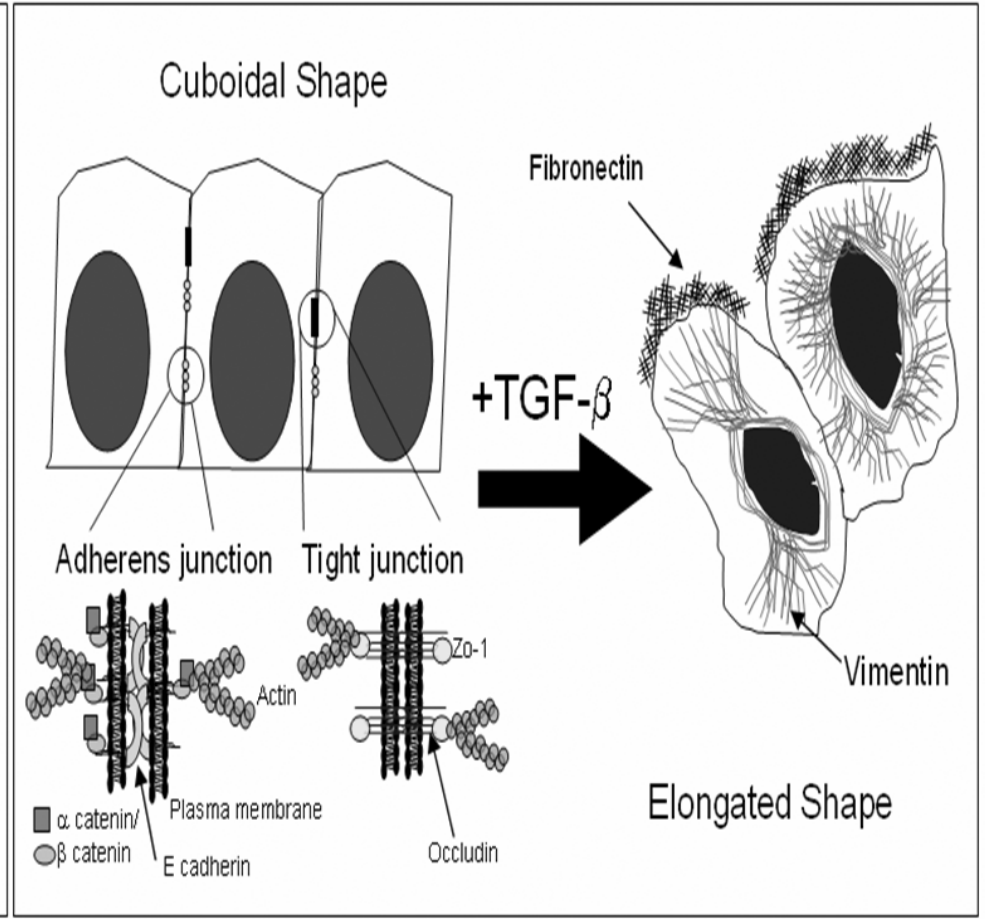

Figure 3 Dual role of TGF- $\beta$ in carcinogenesis. TGF- $\beta$ signaling has been shown to function within both tumor suppression and tumor promotion. (A) In addition to its well-described role regulating G1 transition, TGF- $\beta$ facilitates cellular responses to DNA damage, including the activation of p53 and the suppression of cells with irradiation-induced centrosomal amplification. Potential targets to facilitate TGF- $\beta$-mediated p53 activation include ATM and Chk2. Thus, TGF- $\beta$ signaling is essential for the maintenance of genetic stability within mammary epithelia. (B) At later stages, transformed cells resist the growth suppressive effects of TGF- $\beta$ signaling. Many reports demonstrate that TGF- $\beta$ signaling promotes the loss of epithelial characteristics, such as adherins and tight junctions with down-regulation of E-cadherin and Zo-1 respectively, and the acquisition of mesenchymal characteristics, such as increased intracellular vimentin and secretion of fibronectin. These TGF- $\beta$-mediated transitions require, or are accompanied by, concurrent activation of multiple growth-promoting pathways including the MAPK and phosphatidylinositol 3-kinase (PI3K). 
however, TGF- $\beta$ promotes tumor progression through the induction of epithelial to mesenchymal transition (EMT) (Roberts \& Wakefield 2003, Siegel \& Massague 2003) (Fig. 3B). The following section will outline the dual nature of TGF- $\beta$, and its interplay with hormonal effects, within tumorigenesis. Emphasis will be placed upon the role of TGF- $\beta$ within radiation-induced mammary carcinogenesis. As ionizing radiation (IR) represents a wellestablished carcinogen (Gofman 1990) and IR induces stress responses at the cellular (i.e. p53 activation and growth arrest), tissue (i.e. apoptosis) and endocrine level, IR-induced mammary carcinogenesis is an exceptional model to examine the duality of TGF- $\beta$ in hormonally regulated cancers.

\section{TGF- $\beta$ functions as a tumor suppressor through p53 activation, growth arrest and apoptosis}

The seminal importance of hormones to mammary tumorigenesis is highlighted by epidemiological data that demonstrates a $50 \%$ reduction in breast cancer risk subsequent to one full term pregnancy (Rosner et al. 1994). It was postulated that the protective effect of hormones in mammary carcinogenesis might, in part, be related to regulation of p53 activation (Becker et al. 2005). Proof of principle experiments examining p53-deficient mammary tissues demonstrated a lack of parity-induced protection, confirming the participation of p53 in hormonal-mediated chemoprevention (Medina \& Kittrell 2003). The tumor suppressor p53 is the major sensor and signal to promote apoptosis and cell cycle arrest following cellular stress. The apoptotic response eliminates cells with carcinogenic potential whereas cell cycle arrest provides time to accomplish DNA repair. The p53-mediated cellular stress response includes fast, post-translational modifications of p53 protein stability following DNA damage. The changes include stabilization and tetramerization of the $\mathrm{p} 53$ protein through a complex series of covalent $\mathrm{p} 53$ protein modifications such as serine phosphorylation and de-phosphorylation. Once activated, p53 acts at the trailhead of transcriptional, cell cycle, repair and apoptotic responses.

Radiation-induced TGF- $\beta$ activation and signaling, like p53 stability, is rapid (Ewan et al. 2002b). Moreover, TGF- $\beta$ gene status significantly impacts cellular damage response. Radiation-induced apoptosis is absent in $T g f \beta 1+/-$ mammary epithelium and cell cycle arrest is a function of
TGF- $\beta$ gene status in embryo epithelium (Ewan et al. 2002b). TGF- $\beta$ signaling does not affect the abundance of $\mathrm{p} 53$ protein but rather its posttranslational modification and stabilization (Ewan et al. $2002 b$ ). Recent analyses demonstrate a direct cross talk between TGF- $\beta$ and hormones in the process of $\mathrm{p} 53$ activation within irradiated mammary epithelium. In ovariectomized mice, systemic injections of estrogen and progesterone were necessary to recover maximal expression of cell cycle regulators following ionizing radiation (Becker et al. 2005). While ovarian steroid hormone administration augmented the p53 response to radiation (Becker et al. 2005), neutralization of TGF- $\beta$ blocked responsiveness (Ewan et al. 2002b). The surprising conclusion from these experiments is that TGF- $\beta$, representing an extracellular signaling molecule, determines p53 response to DNA damage caused by radiation.

TGF- $\beta$ and p53 display many similarities and some events originally attributed to p53 are actually directly inducible by TGF- $\beta$ : GADD-45 and $\mathrm{WAF} / \mathrm{p} 21$ can be induced by TGF- $\beta$ treatment of transformed keratinocytes without functional p53 (Landesman et al. 1997) and TGF- $\beta$ activates c-jun amino terminal kinase involved in UVmediated apoptosis (Merryman et al. 1998). On the other hand, p53 action largely overlaps with TGF$\beta$ effects (Cordenonsi et al. 2003, TakebayashiSuzuki et al. 2003). Mutant p53 correlates with reduced TGF- $\beta$ responsiveness in human bronchial epithelial cells (Gerwin et al. 1992), murine keratinocytes (Reiss et al. 1993) and thyroid epithelial cells (Wyllie et al. 1991). In the early phase of mammary involution, TGF- $\beta$ leads to an eightfold increase in p21/WAF mRNA, and p53 can be detected on transcriptional as well as on protein level (Strange et al. 1992, Jerry et al. 1998). However, the radiation-induced p21 response is absent in p53 - / - mice (Strange et al. 1992). Interestingly, p53 participates in TGF- $\beta$ signaling (Cordenonsi et al. 2003), which complicates interpretation but suggests a mutual enhancement of response to damage.

The mechanisms by which ovarian steroid hormones and TGF- $\beta$ act to increase the p53 response in the mammary epithelium are of potential therapeutic interest. Jerry and coworkers ruled out direct DNA damage as well as direct transcriptional regulation as potential mechanisms by which these hormones regulate p53 activation (Becker et al. 2005). Moreover, as TGF- $\beta$ gene dose affects radiation-induced p53 phosphorylation and not total protein, it is likely that estrogen + progesterone 
and TGF- $\beta$ regulate $\mathrm{p} 53$ through an indirect posttranslational mechanism (Ewan et al. 2002b). Such a mechanism could incorporate additional binding factors, such as chk2 (checkpoint kinase 2), ATM (ataxia telangiectasia mutated), plk1 (polo-like kinase 1) and BRCA1, that affect p53 activation (Chehab et al. 1999, Khosravi et al. 1999, Somasundaram et al. 1999, Hirao et al. 2002 Ando et al. 2004). The relative abundance of these gene products may be altered subsequent to TGF- $\beta$ or hormonal signaling with consequent alterations in p53 stability. Alternatively, TGF- $\beta$ and hormones may directly alter p53 stability. Mechanistically the $\mathrm{ER} \alpha$ complexes with $\mathrm{p} 53$ protein, leading to stabilization of p53 (Liu et al. 2000) and altered transcriptional responses to estrogen (Liu et al. 1999). TGF- $\beta$ signaling, through the induction of Smads, may alter hormonal receptor responses. Some ER $\alpha$-positive breast cancer cells are refractory to TGF- $\beta$-mediated growth arrest due to the reduced expression of T $\beta R I$ and T $\beta$ RII through transcriptional repression (Kim et al. 2000). Smads are induced by antiestrogens (Buck et al. 2004), have been shown to bind $\mathrm{ER} \alpha$ (Matsuda et al. 2001, Yamamoto et al. 2002, Wu et al. 2003) and may represent the point of cross talk between these two signaling pathways. Indeed, activation of a bone morphogenetic protein (BMP)/Smad1 pathway characterizes breast cancers and is a major hallmark of the progression and dedifferentiation of estrogen-positive breast cancer (Helms et al. 2005). Thus, steroid hormones and TGF- $\beta$ likely cooperate to balance the induction of factors that alter the activation and stabilization of p53, leading to elimination of damaged and potentially oncogenic cells.

\section{TGF- $\beta$ regulation of genomic stability through the centrosome and proteasome}

p53 has been defined as a quintessential tumor suppressor through its ability to regulate apoptosis, DNA repair and cell cycle arrest (reviewed in Brown \& Attardi 2005, Sengupta \& Harris 2005). However, recent examination of p53 function and localization illustrate an intimate association between p53 and a small sub-cellular organelle named the centrosome (reviewed in Tarapore \& Fukasawa 2002). The centrosome, named for its frequent localization at the cell center, is the major microtubule organizer in many cell types. In addition to maintaining cytoskeletal architecture through nucleation and organization of microtubules, the centrosome participates in a number of processes including cell motility, polarity, signaling, damage responses and division. During cell division, the centrosome is duplicated once during $\mathrm{S}$ phase and it is these duplicated centrosomes that functionally nucleate the bipolar mitotic apparatus necessary for division. p53 regulates centrosomal fidelity and loss of p53 induces centrosomal abnormalities with consequent genetic instability (reviewed in Tarapore \& Fukasawa 2002, Salisbury et al. 2004). Importantly, centrosomal abnormalities, defined based upon abnormal number, size or shape, have been identified in the majority of tumors examined (Pihan et al. 1998) and have been implicated in the generation of chromosomal instability (CIN) and tumorigenesis (Pihan et al. 2001, 2003, Salisbury et al. 2004).

In primary human breast cancer, centrosomal abnormalities are prevalent, occur early (Salisbury et al. 2004) and are significantly associated with hormone receptor status (Schneeweiss et al. 2003). However, progesterone increases aneuploidy in p53 null tumor cells without associated centrosomal amplification (Goepfert et al. 2000). In a rodent model of estrogen-mediated mammary tumorigenesis, estrogen supplementation induced overexpression of a regulatory centrosomal protein, Aurora A kinase, as well as near complete prevalence of centrosomal amplification in mammary tumors accompanied with genetic aberrations ( $\mathrm{Li}$ et al. 2004). While there are strong interconnections between hormonal exposure, centrosomal amplification and mammary tumorigenesis, to date there are no published direct links between exogenous TGF- $\beta$ and centrosomal dysregulation.

Glick and colleagues have shown that $\operatorname{Tg} f \beta 1$ null keratinocytes demonstrate elevated genomic instability, as measured by $\mathrm{N}$-(phosphonacetyl)-Laspartic acid (PALA)-induced gene amplification, and lack the typical PALA-induced, p53-dependent growth arrest despite functionally wild-type p53 activity (Glick et al. 1996). Moreover, v-ras ${ }^{\mathrm{Ha}}$ transduced $T g f \beta 1$ null keratinocytes rapidly developed aneuploidy with multiple mitotic aberrations (Glick et al. 1996, 1999). Given the intimate association between TGF- $\beta$, p53 activation and aneuploidy, we investigated whether TGF- $\beta$, like $\mathrm{p} 53$, also participates in the regulation of centrosomal amplification. Compromised TGF- $\beta$ production or signaling in either murine keratinocytes or human mammary epithelial cells induces elevated centrosomal amplification in spite of functional p53 within these non-malignant epithelial cells 
(authors' unpublished observations). Centrosomal amplification subsequent to irradiation has been reported in cancer cell lines of various species and is almost invariably associated with a prolonged G2 cell cycle arrest (Sato et al. 1983, 2000, Shono et al. 2001, Dodson et al. 2004, Kawamura et al. 2004, Yoon et al. 2005). Interestingly, the absence of exogenous TGF- $\beta$ sensitizes irradiated, p53competent human mammary epithelial cells (HMEC) to persistent centrosomal amplification and the addition of TGF- $\beta$ impairs the permanence, but not induction, of these abnormalities (authors' unpublished observations). These results suggest that $\mathrm{p} 53$-competent HMEC require TGF- $\beta$ signaling to properly supervise irradiation-induced cellular stress.

An additional consideration for these TGF- $\beta$ mediated processes may be the regulation of the proteasome. While it is beyond the scope of this review, it is warranted to mention that irradiation dramatically changes the composition of the proteasome as well as its activity, with subsequent consequences on DNA repair, cell cycle progression (through regulation of cyclin E, p53 and p21 expression) and cell death (reviewed in McBride et al. 2003). The proteasome is also intimately associated with centrosomal stability, as various components of the proteasome/ubiquitin pathway localize to centrosomes (Freed et al. 1999, Wigley et al. 1999, Nakayama et al. 2000) and inhibition of proteasomal activity is sufficient to induce multipolar spindle phenotypes (Ehrhardt \& Sluder 2005). As outlined above, the role of the proteasome/ubiquitin pathway in regulating TGF- $\beta$ signaling is well established. Hormones and their receptors also affect and are regulated by ubiquitin-mediated protein degradation (Hamel et al. 2004, Laios et al. 2005), while radiation rapidly inhibits proteosome function (McBride et al. 2003).

One gene product that highlights the interconnectivity of hormones, TGF- $\beta$, centrosomes and proteasomal activity is breast cancer 1 (BRCA1). The BRCA1 gene was first localized by genetic linkage in 1994 and loss of function mutations of BRCA1 have been reported to confer up to an $82 \%$ risk of developing breast cancer and a $54 \%$ risk of developing ovarian cancer by the age of 80 years (reviewed in Kennedy et al. 2004). The major role of BRCA1 is to respond to DNA damage and thus it is important in DNA repair, transcriptional regulation, cell cycle regulation, proteolysis and centrosomal stability (Kennedy et al. 2004). BRCA1 localizes to centrosomes during mitosis
(Hsu \& White 1998), interacts directly with the key centrosomal structural protein $\gamma$-tubulin (Hsu et al. 2001) and may serve as a negative regulator of centrosomal duplication (reviewed in Deng 2002). Indeed, disruption of BRCA1 function induces centrosomal amplification specifically within mammary cell lines (Starita et al. 2004). Mechanistically, BRCA1 and its binding partner BARD1, together a highly active E3 ubiquitin ligase (Hashizume et al. 2001), target $\gamma$-tubulin turnover through mono-ubiquitination; loss of this regulation, through inhibition of BRCA1 or alteration of $\gamma$-tubulin, results in mammary-specific centrosome amplification (Starita et al. 2004). Reduction of BRCA1 also disrupts mammary epithelial cell morphogenesis within an in vitro 3D culture system in a manner that is reversible by addition of unidentified soluble factors (Furuta et al. 2005).

While hereditary breast cancers, associated with germ-line BRCA1 mutations, are not associated with a higher frequency of $T \beta R$ inactivation than sporadic cases (Xie et al. 2002), increasing evidence suggests significant cross-talk between TGF- $\beta$ signaling and BRCA1 function. TGF- $\beta 1$ inhibits BRCA1 expression in a Rb-dependent manner within Mv1Lu cells (Satterwhite et al. 2000). Swift, an important constituent of embryonic TGF $\beta$ induced gene transcription, contains a BRCA Cterminal (BRCT) domain that directly interacts with and co-activates Smad2 (Shimizu et al. 2001). Smad3 also directly interacts with the BRCT domain of BRCA1 and TGF- $\beta /$ Smad3-modified BRCA1-dependent repair of DNA double strand (Dubrovska et al. 2005). TGF- $\beta$-mediated regulation of BRCA1, and other DNA damage response proteins such as p53 and ATM, may dramatically alter centrosomal amplification, proteasomal activity and genetic stability following irradiation.

The preceding studies demonstrating TGF- $\beta$ mediated supervision of centrosomal abnormalities may indicate reciprocity between TGF- $\beta$ and hormonal signaling, proteasomal activity and centrosomal stability. Given these intimate associations, it is likely that cellular homeostasis is maintained through the cumulative cross talk of extracellular signals and intracellular regulatory mechanisms. Carcinogens such as ionizing radiation may disrupt this homeostasis and result in intracellular aberrations (i.e. centrosomal abnormalities, increased/aberrant proteasomal activity) that are supervised by extracellular cues. To some extent, TGF- $\beta$ mediates the proper supervision of these 
aberrations. However, this supervision may be incomplete in some contexts such as in early preneoplastic lesions in which TGF- $\beta$ signaling is perturbed or lost. Within the context of incomplete supervision and subsequent persistent aberrations, TGF- $\beta$ signaling can cooperate with ionizing radiation to promote cellular programs that are tumorigenic, such as EMT.

\section{TGF- $\beta$ during tumor progression and EMT}

Several lines of evidence underscore the transition of TGF- $\beta$ as it switches from tumor suppression to tumor promotion. Paradoxically for a tumor suppressor, when compared with normal tissue, production of TGF- $\beta$ is increased in breast (Travers et al. 1988, Gorsch et al. 1992, Dalal et al. 1993), gastric (Maehara et al. 1999) and prostate cancer (Steiner et al. 1994). Inhibition of TGF- $\beta$ reduces tumor cell motility and metastasis in genetically induced murine mammary tumors (Muraoka et al. 2002) and over-expression of active TGF- $\beta$ in vivo accelerates metastases of transgenic mammary tumors (Muraoka-Cook et al. 2004). In addition to increased TGF- $\beta$ production, expression levels of I-Smads are often altered in tumor microenvironments. Smad7 is expressed at very low levels in epithelial tissues, but it is upregulated in human pancreatic (Kleeff et al. 1999), endometrial (Dowdy et al. 2005) and colorectal cancers (Korchynskyi et al. 1999). While Smad7 can induce tumorigenicity by blocking growth arrest and apoptosis within a TGF- $\beta$ sensitive cell line (Halder et al. 2005), Smad7 over-expression can also functionally inactivate $\mathrm{Rb}$ without interfering with Smad2/3 nuclear translocation (Boyer \& Korc 2005). Thus, these cells are competent for TGF- $\beta$ modulation of gene expression, such as increased plasminogen activator inhibitor (PAI)-1 expression in response to TGF- $\beta$, but are resistant to the growth inhibitory mechanisms of TGF- $\beta$ signaling (Boyer \& Korc 2005). These results have implication for cancer cells that are responsive to TGF- $\beta$-mediated EMT but unresponsive to cell cycle inhibition and apoptosis.

Many tumor-promoting aspects of TGF- $\beta$ are related to tumor cell motility and metastasis. One mechanism by which TGF- $\beta$ can promote motility is through the induction of epithelial to mesenchymal transition (EMT) (Akhurst \& Balmain 1999). Cells undergoing EMT must counteract TGF- $\beta$-mediated growth control, dramatically alter shape and dissolve tight junctions and downregulate epithelial markers and remodel cytoskeletal networks to acquire motile phenotypes. Cumulatively, these transformations can facilitate increased migration and metastasis (Thiery 2002). However, induction of EMT by TGF- $\beta$ alone is a rare event in vitro (Brown et al. 2004). The rarity of TGF- $\beta$ mediated EMT in non-malignant cells is likely attributable to the requirement for simultaneous activation of multiple signaling pathways orchestrating proliferation, survival and differentiation.

\section{TGF- $\beta$ role in overcoming growth restrictions during EMT}

Several reports suggest that an independent stimulus for cell proliferation must synergistically proceed or at least accompany the induction of EMT (Gotzmann et al. 2004). Consequently, constitutive activation of downstream signaling pathways, such as MAP kinase (MAPK) or PI3K, may be a requirement to induce a pre-malignant state and endow epithelial cells with an increased rate of proliferation (Gotzmann et al. 2004). In addition to counteracting the anti-proliferative and apoptotic effects of TGF$\beta$, these cells must functionally switch differentiation programs. Recent evidence indicates a central role for Disabled-2 (Dab-2) within some of these processes. During the promotion of EMT within non-transformed murine mammary gland cells, TGF- $\beta$ induces the expression of Dab-2 (Prunier \& Howe 2005), a protein that functions in the regulation of the cytoskeleton and epithelial differentiation (Sheng et al. 2000). TGF- $\beta$ also induces Dab-2 accumulation at the membrane and consequent binding to $\beta 1$-integrin with subsequent integrin activation and protection from apoptosis (Prunier $\&$ Howe 2005). Another important intermediate is integrin-linked kinase (ILK). ILK expression is responsive to TGF- $\beta$ treatment and ectopic expression of ILK induces E-cadherin and fibronectin expression and assembly within renal tubular epithelial cells (Li et al. 2003). Moreover, kinase dead ILK largely abolishes EMT within renal epithelia (Li et al. 2003). Similar results have been demonstrated within human keratinocytes; within these cells, ILK is required for TGF- $\beta$-mediated EMT through propagation of the PI3K-AKT pathway (Lee et al. 2004). These results underscore the importance of coincident activation of pathways that promote cell survival, in this case integrin-dependent cell adhesion and survival, during TGF- $\beta$-induced EMT. 


\section{TGF- $\beta$ role in dissolution of tight junctions during EMT}

Many signaling pathways are important for the acquisition of EMT including the canonical Ras pathway, PI3K and the MAPK pathways (Grunert et al. 2003, Thiery 2003). In addition to Ras pathways, TGF- $\beta$ signaling cooperates with $\beta 1$ integrin, PI3K, RhoA and protein kinase $(\mathrm{PK}) \mathrm{C}-\zeta$ to induce cell scattering, defined as loss of polarity and epithelial markers combined with gain of a mesenchymal gene program and migratory phenotypes (Grunert et al. 2003). Recent high throughput protein-protein interactome mapping of the TGF- $\beta$ pathway has identified novel, potential EMT targets including key regulators of epithelial cytoskeletal networks, polarity and structural components of tight junctions (Barrios-Rodiles et al. 2005, Ozdamar et al. 2005). One such component of tight junctions, occludin (OCLN), interacts with T $\beta$ RII in a TGF- $\beta$-dependent manner and dominant negative OCLN prevents TGF- $\beta$-dependent dissolution of tight junctions during EMT (Barrios-Rodiles et al. 2005). Recent investigations within tubular cells demonstrate the importance of cell-cell junctions and their disruption during tissue injury and repair in the initiation of EMT (Masszi et al. 2004). Indeed, the authors suggested a two-hit model during which both an initial injury, leading to losses of cell-cell contacts and redistribution of $\beta$-catenin, and TGF- $\beta$ are required for EMT (Masszi et al. 2004). In normal murine mammary gland cells, another key participant in TGF- $\beta$ dependent dissolution of tight junctions is Par6 (Ozdamar et al. 2005). Par6, like OCLN, interacts with TGF- $\beta$ receptors and Par6 is phosphorylated by T $\beta$ RII leading to an association with Smurf1 and the localized degradation of RhoA (Ozdamar et al. 2005). Par6 mutants, inhibition of proteasomal activity or mutation of RhoA acceptor sites for ubiquitin block TGF- $\beta$-induced tight junction dissolution (Ozdamar et al. 2005). Interestingly, morphological changes similar to EMT (reduced OCLN, tight junctions and E-cadherin) were observed in estrogen receptor $\beta$ knockout mice (Forster et al. 2002) and exogenous 17 $\beta$-estradiol modulates occludin expression probably through post translational stabilization (Zeng et al. 2004). Moreover, Par6 was identified as a target gene of steroid receptor coactivator-3 (SRC-3) (Labhart et al. 2005), a co-activator of ER $\alpha$-dependent gene regulation (Suen et al. 1998). As with p53 activation, cross-talk between hormonal and TGF- $\beta$-mediated signaling pathways may be a vital determinant of EMT-induced structural changes.

\section{The effects of TGF- $\beta$ inhibitors within cancer models}

An understanding of the multiple and complex mechanisms of TGF- $\beta$ regulation of epithelial function, and ultimate loss of function, will be critical in the design of novel therapeutic interventions for endocrine-related cancers. The restricted and stringently regulated activation of TGF- $\beta$ found in normal tissue contrasts with the elevated TGF- $\beta$ expression observed in tumors.

Mouse models of early stage epithelial cancers suggest that most are sensitive to TGF- $\beta$ growth inhibition (Akhurst 2002). Early stage cancers may be suppressed by TGF- $\beta$-mediated alterations in the stroma composition and stimulation of immune system surveillance (Akhurst 2002). Older women with a TGF $\beta 1$ polymorphism, which results in more TGF- $\beta$ secretion, are less likely to develop breast cancer (Ziv et al. 2001), and as mentioned before, one of the most effective breast cancer prevention therapeutics, tamoxifen, appears to induce TGF- $\beta$. As would be expected, tumors routinely develop traits that circumvent TGF- $\beta$ inhibition, yet surprisingly continue to produce and may even increase their ability to activate TGF- $\beta$. Essentially, all studies to date indicate that TGF- $\beta$ is increased in tumors versus normal tissue. TGF- $\beta$ immunoreactivity correlates with breast cancer progression (Gorsch et al. 1992), abnormal stroma (McCune et al. 1992), and metastases (Dalal et al. 1993). Human tumors also exhibit elevated TGF- $\beta$ mRNA (Barrett-Lee et al. 1990, Murray et al. 1993), immunoreactivity (Butta et al. 1992, Dublin et al. 1993, Mahara et al. 1994) and protein (Godden et al. 1993). Thus, TGF- $\beta$ has been targeted for pharmacological manipulation in cancer diagnosis and therapy (Dickens \& Colletta 1993, Yingling et al. 2004). But the broad range and complex timing of events that are potentially modulated by TGF- $\beta$ is a challenge for pharmaceutical exploitation.

Several strategies have arisen from studies of the basic biology of TGF- $\beta$. Thrombospondin was shown to bind and activate LTGF- $\beta$ (SchultzCherry et al. 1994). Recent structural studies have identified a thrombospondin RKPK peptide sequence that can both block re-association of LAP and TGF- $\beta 1$, thereby neutralizing the ability of TGF- $\beta$ to bind its receptors, and induce 
activation, presumably by disrupting LAP-mature TGF- $\beta$ interactions (Young \& Murphy-Ullrich 2004). Decorin, an extracellular proteoglycan, can also inhibit TGF- $\beta$ (Border et al. 1992, Kolb et al. 2001). These naturally occurring inhibitors of TGF- $\beta$ are presumably part of an environmental control to prevent rampant TGF- $\beta$ activation, and may provide insight into the selectivity of its effects in vivo.

Recent studies have examined small molecule inhibitors of TGF- $\beta$. A novel small molecule of quinazoline-derived inhibitors of the type I transforming growth factor receptor was shown to be effective in cell culture. This molecule inhibits the kinase by binding to the ATP-binding site to keep the kinase in its inactive conformation (Ge et al. 2004). Another member (SB-505124) of a new class of small molecule inhibitors related to imidazole inhibitors of $\mathrm{p} 38$ inhibits the TGF- $\beta$-type I receptor serine/threonine kinase known as activin receptorlike kinase (ALK) 5. Selectively and concentration dependently this compound inhibits ALK 5-, and also ALK 4 (activin receptor)- and ALK 7 (nodal receptor)-dependent activation of downstream cytoplasmic signal transducers, Smad2 and Smad3 and of TGF- $\beta$-induced MAPK pathway components (DaCosta et al. 2004). Interestingly, it is selective in that it was shown not to alter ALK 1-, 2-, 3-, or 6induced Smad signaling. Since integrins can also mediate activation of LTGF- $\beta$, the ability of a small-molecule inhibitor of integrin $\alpha \mathrm{v} \beta 3$, SB223245 , to block the interaction may be a means of blocking TGF- $\beta$ (Ludbrook et al. 2003).

Neutralizing antibodies to TGF- $\beta$ have also been used in animal models. Anti-TGF- $\beta$ monoclonal antibodies prevent the cyclosporine-induced increase in the number of metastases (Hojo et al. 1999), block radiation-induced collagen remodeling (Ehrhart et al. 1997) and Smad signaling (SchultzeMosgau et al. 2004), and inhibit establishment of MDA-231 tumors and lung metastases in athymic mice (Arteaga et al. 1993).

\section{Therapeutic potential of inhibitors of TGF- $\beta$}

Considering the pleiotropic effects of TGF- $\beta$, the timing and duration of inhibition is likely to be critical to the ultimate benefit. There may be scenarios in which TGF- $\beta$ inhibition in conjunction with cancer therapy is beneficial. The most developed experimental evidence is that from radiotherapy, where there is a clear benefit in experimental normal tissue toxicity models for blocking TGF- $\beta$.
Russo and colleagues have used a small molecular weight molecule, halofuginone, to block TGF- $\beta$ signaling using a connective tissue radiation damage model (Xavier et al. 2004). Halofuginone inhibits the TGF- $\beta$ signaling pathway by elevating inhibitory Smad7, blocking formation of phosphoSmad2 and phospho-Smad3 and decreasing cytosolic and membrane TGF- $\beta$ type II receptor. Halofuginone treatment significantly lessened radiation-induced fibrosis but showed neither general toxicity nor interference with tumor control by radiation in mice. Interestingly, it appears that even transient inhibition is beneficial, which is likely to be rooted in the self-amplification of autocrine loops by TGF- $\beta$ and its mediators. Transient expression of soluble TGF- $\beta$ type II receptor by adenovirus infection shows promise in some experimental models of normal lung damage following radiotherapy (Rabbani et al. 2003a, Nishioka et al. 2004). It is likely that interruption of TGF- $\beta$ signaling significantly affects its own production, thus limiting the source of protein as well as the means to activate it. Studies in a rat lung radiation-injury model by Vujaskovic and colleagues have shown that blocking TGF- $\beta$ via expression of soluble type II receptor decreases reactive oxygen species (ROS), and blocking ROS by pharmaceuticals or by over-expression of superoxide dismutase decreases TGF- $\beta$ (Rabbani et al. $2003 a, b)$, consistent with a detrimental cascade in which TGF- $\beta$ is activated by ROS, which in turn stimulates ROS, that can then activate more TGF$\beta$. Even transient interruption of this process has significant long-term benefit by limiting normal tissue damage.

\section{Summary}

The 25 -year history of TGF- $\beta$ has been productive and informative as to fundamental growth control by extracellular factors and the loss of such regulation during cancer progression. TGF- $\beta$ has confounded, perplexed and rewarded researchers who have struggled to understand its complex biology. The relatively recent appreciation of its role in modulating response to hormones offers a new perspective on its potential application to the treatment of endocrine-related cancers.

\section{Funding}

This work was funded, in part, by the Office of Health and Environmental Research, Health Effects 
Division, United States Department of Energy (contract no.03-76SF00098) and the National Institute of Environmental Health Sciences, NIH, grant number U01 ES012801 to M-H B-H. The authors declare that there is no conflict of interest that would prejudice the impartiality of this scientific work.

\section{References}

Akhurst RJ 2002 TGF- $\beta$ antagonists: why suppress a tumor suppressor? Journal of Clinical Investigation 109 1533-1536.

Akhurst RJ \& Balmain A 1999 Genetic events and the role of TGF beta in epithelial tumour progression. Journal of Pathology 187 82-90.

Al-Hajj M, Wicha MS, Benito-Hernandez A, Morrison SJ \& Clarke MF 2003 From the Cover: prospective identification of tumorigenic breast cancer cells. PNAS $\mathbf{1 0 0}$ 3983-3988.

Ando K, Ozaki T, Yamamoto H, Furuya K, Hosoda M, Hayashi S, Fukuzawa M \& Nakagawara A 2004 Polo-like kinase 1 (Plk1) inhibits p53 function by physical interaction and phosphorylation. Journal of Biological Chemistry 279 25549-25561.

Annes JP, Chen Y, Munger JS \& Rifkin DB 2004 Integrin $\alpha \mathrm{V} \beta 6$-mediated activation of latent TGF- $\beta$ requires the latent TGF- $\beta$ binding protein-1. Journal of Cell Biology $165723-734$.

Arteaga CL, Hurd SD, Winnier AR, Johnson MD, Fendly BM \& Forbes JT 1993 Anti-transforming growth factor (TGF)- $\beta$ antibodies inhibit breast cancer cell tumorigenicity and increase mouse spleen natural killer cell activity. Journal of Clinical Investigation 92 2569-2576.

Arteaga CL, Koli KM, Dugger TC \& Clarke R 1999 Reversal of tamoxifen resistance of human breast carcinomas in vivo by neutralizing antibodies to transforming growth factor-beta. Journal of the National Cancer Institute 91 46-53.

Baldwin RL, Tran H \& Karlan BY 2003 Loss of c-myc repression coincides with ovarian cancer resistance to transforming growth factor beta growth arrest independent of transforming growth factor beta/Smad signaling. Cancer Research 63 1413-1419.

Barcellos-Hoff MH 1996 Latency and activation in the regulation of TGF- $\beta$. Journal of the Mammary Gland Biology Neoplasia 3 353-363.

Barcellos-Hoff MH \& Ewan KB 2000 TGF- $\beta$ and mammary gland development. Breast Cancer Research 2 92-100.

Barcellos-Hoff MH, Derynck R, Tsang ML-S \& Weatherbee JA 1994 Transforming growth factor- $\beta$ activation in irradiated murine mammary gland. Journal of Clinical Investigation 93 892-899.

Barrett-Lee P, Travers M, Luqmani Y \& Coombes RC 1990 Transcripts for transforming growth factors in human breast cancer: clinical correlates. British Journal of Cancer $61612-617$.
Barrios-Rodiles M, Brown KR, Ozdamar B, Bose R, Liu Z, Donovan RS, Shinjo F, Liu Y, Dembowy J, Taylor IW et al. 2005 High-throughput mapping of a dynamic signaling network in mammalian cells. Science $\mathbf{3 0 7}$ 1621-1625.

Becker KA, Lu S, Dickinson ES, Dunphy KA, Mathews L, Schneider SS \& Jerry DJ 2005 Estrogen and progesterone regulate radiation-induced p53 activity in mammary epithelium through TGF-beta-dependent pathways. Oncogene 24 6345-6353.

Border WA, Noble NA, Yamamoto T, Harper JR, Yamaguchi Y, Pierschbacher MD \& Ruoslahti E 1992 Natural inhibitor of transforming growth factor- $\beta$ protects against scarring in experimental kidney disease. Nature 360 361-364.

Böttinger EP, Letterio JJ \& Roberts AB 1997 Biology of TGF-beta in knockout and transgenic mouse models. Kidney International 51 1355-1360.

Boulanger CA \& Smith GH 2001 Reducing mammary cancer risk through premature stem cell senescence. Oncogene $\mathbf{2 0}$ 2264-2272.

Boyer AN \& Korc M 2005 Smad7 abrogates transforming growth factor-betal-mediated growth inhibition in COLO-357 cells through functional inactivation of the retinoblastoma protein. Journal of Biological Chemistry $28021858-21866$.

Brown JM \& Attardi LD 2005 The role of apoptosis in cancer development and treatment response. Nature Reviews in Cancer 5 231-237.

Brown KA, Aakre ME, Gorska AE, Price JO, Eltom SE, Pietenpol JA \& Moses HL 2004 Induction by transforming growth factor-betal of epithelial to mesenchymal transition is a rare event in vitro. Breast Cancer Research 6 R215-R231.

Buck MB, Pfizenmaier K \& Knabbe C 2004 Antiestrogens induce growth inhibition by sequential activation of p38 mitogen-activated protein kinase and transforming growth factor-beta pathways in human breast cancer cells. Molecular Endocrinology 18 1643-1657.

Buggiano V, Schere-Levy C, Abe K, Vanzulli S, Piazzon I, Smith GH \& Kordon EC 2001 Impairment of mammary lobular development induced by expression of TGFbetal under the control of WAP promoter does not suppress tumorigenesis in MMTV-infected transgenic mice. International Journal of Cancer 92 568-576.

Butta A, MacLennan K, Flanders KC, Sacks NPM, Smith I, McKinna A, Dowsett M, Wakefield LM, Sporn MB, Baum M et al. 1992 Induction of transforming growth factor $\beta 1$ in human breast cancer in vivo following tamoxifen treatment. Cancer Research 52 4261-4264.

Chehab NH, Malikzay A, Stavridi ES \& Halazonetis TD 1999 Phosphorylation of Ser-20 mediates stabilization of human p53 in response to DNA damage. PNAS 96 13777-13782.

Chen H, Tritton TR, Kenny N, Absher M \& Chiu JF 1996 Tamoxifen induces TGF-beta 1 activity and apoptosis of human MCF-7 breast cancer cells in vitro. Journal of Cell Biochemistry 61 9-17. 
Chen CR, Kang Y, Siegel PM \& Massague J 2002 E2F4/5 and p107 as Smad cofactors linking the TGFbeta receptor to c-myc repression. Cell 110 19-32.

Cheng N, Bhowmick NA, Chytil A, Gorksa AE, Brown KA, Muraoka R, Arteaga CL, Neilson EG, Hayward SW \& Moses HL 2005 Loss of TGF-beta type II receptor in fibroblasts promotes mammary carcinoma growth and invasion through upregulation of TGF-alpha-, MSPand HGF-mediated signaling networks. Oncogene $\mathbf{2 4}$ 5053-5068.

Choudhury A, Singh RK, Moniaux N, El-Metwally TH, Aubert JP \& Batra SK 2000 Retinoic acid-dependent transforming growth factor-beta 2-mediated induction of MUC4 mucin expression in human pancreatic tumor cells follows retinoic acid receptor-alpha signaling pathway. Journal of Biological Chemistry 275 33929-33936.

Clarke RB, Howell A, Potten CS \& Anderson E 1997 Dissociation between steroid receptor expression and cell proliferation in the human breast. Cancer Research $\mathbf{5 7}$ 4987-4991.

Cordenonsi M, Dupont S, Maretto S, Insinga A, Imbriano C \& Piccolo S 2003 Links between tumor suppressors: p53 is required for TGF-beta gene responses by cooperating with Smads. Cell 113 301-314.

DaCosta BS, Major C, Laping NJ \& Roberts AB 2004 SB-505124 is a selective inhibitor of transforming growth factor-beta type I receptors ALK4, ALK5, and ALK7. Molecular Pharmacology 65 744-752.

Dalal BI, Keown PA \& Greenberg AH 1993 Immunocytochemical localization of secreted transforming growth factor- $\beta 1$ to the advancing edges of primary tumors and to lymph node metastases of human mammary carcinoma. American Journal of Pathology 143 381-389.

Dallas SL, Sivakumar P, Jones CJ, Chen Q, Peters DM, Mosher DF, Humphries MJ \& Kielty CM 2005 Fibronectin regulates latent transforming growth factorbeta (TGF beta) by controlling matrix assembly of latent TGF beta-binding protein-1. Journal of Biological Chemistry 280 18871-18880.

Daniel CW, Silberstein GB, Van Horn K, Strickland P \& Robinson S 1989 TGF- $\beta 1$-induced inhibition of mouse mammary ductal growth: developmental specificity and characterization. Developmental Biology 135 20-30.

Danielpour D 2005 Functions and regulation of transforming growth factor-beta (TGF-beta) in the prostate. European Journal of Cancer 41 846-857.

Deng CX 2002 Roles of BRCA1 in centrosome duplication. Oncogene 21 6222-6227.

DeOme KB, Faulkin LJJ, Bern HA \& Blair PB 1959 Development of mammary tumors from hyperplastic alveolar nodules transplanted into gland-free mammary fat pads of female C3H mice. Cancer Research 19 515-520.

Derynck R \& Zhang YE 2003 Smad-dependent and Smadindependent pathways in TGF-beta family signalling. Nature 425 577-584.

Derynck R, Ackhurst RJ \& Balmain A 2001 TGF- $\beta$ signaling in tumor suppression and cancer progression. Nature Genetics 29 117-129.
Dickens T \& Colletta AA 1993 The pharmacological manipulation of members of the transforming growth factor beta family in the chemoprevention of breast cancer. BioEssays 15 71-74.

Dodson H, Bourke E, Jeffers LJ, Vagnarelli P, Sonoda E, Takeda S, Earnshaw WC, Merdes A \& Morrison C 2004 Centrosome amplification induced by DNA damage occurs during a prolonged G2 phase and involves ATM. EMBO Journal 23 3864-3873.

Dowdy SC, Mariani A, Reinholz MM, Keeney GL, Spelsberg TC, Podratz KC \& Janknecht R 2005 Over-expression of the TGF-beta antagonist Smad7 in endometrial cancer. Gynecology and Oncology 96 368-373.

Drummond AE 2005 TGFbeta signalling in the development of ovarian function. Cell Tissue Research 322 107-115.

Dublin EA, Barnes DM, Wang DY, King RJ \& Levison DA 1993 TGF $\alpha$ and TGF $\beta$ expression in mammary carcinoma. Journal of Pathology 170 15-22.

Dubrovska A, Kanamoto T, Lomnytska M, Heldin CH, Volodko N \& Souchelnytskyi S 2005 TGFbeta1/Smad3 counteracts BRCA1-dependent repair of DNA damage. Oncogene 24 2289-2297.

Dupont S, Zacchigna L, Adorno M, Soligo S, Volpin D, Piccolo S \& Cordenonsi M 2004 Convergence of p53 and TGF-beta signaling networks. Cancer Letters $\mathbf{2 1 3}$ 129-138.

Ebisawa T, Fukuchi M, Murakami G, Chiba T, Tanaka K, Imamura T \& Miyazono K 2001 Smurf1 interacts with transforming growth factor-beta type I receptor through Smad7 and induces receptor degradation. Journal of Biological Chemistry 276 12477-12480.

Ehrhardt AG \& Sluder G 2005 Spindle pole fragmentation due to proteasome inhibition. Journal of Cellular Physiology 204 808-818.

Ehrhart EJ, Carroll A, Segarini P, Tsang ML-S \& Barcellos-Hoff MH 1997 Latent transforming growth factor- $\beta$ activation in situ: quantitative and functional evidence following low dose irradiation. FASEB Journal 11 991-1002.

English HF, Santen RJ \& Isaacs JT 1987 Response of glandular versus basal rat ventral prostatic epithelial cells to androgen withdrawal and replacement. Prostate 11 229-242.

Eszlinger M, Krohn K, Frenzel R, Kropf S, Tonjes A \& Paschke R 2004 Gene expression analysis reveals evidence for inactivation of the TGF-beta signaling cascade in autonomously functioning thyroid nodules. Oncogene $\mathbf{2 3}$ 795-804.

Ewan KB, Shyamala G, Ravani SA, Tang Y, Akhurst RJ, Wakefield L \& Barcellos-Hoff MH $2002 a$ Latent TGF- $\beta$ activation in mammary gland: regulation by ovarian hormones affects ductal and alveolar proliferation. American Journal of Pathology 160 2081-2093.

Ewan KB, Henshall-Powell RL, Ravani SA, Pajares MJ, Arteaga C, Warters R, Akhurst RJ \& Barcellos-Hoff MH $2002 b$ Transforming growth factor- $\beta 1$ mediates cellular response to DNA damage in situ. Cancer Research $\mathbf{6 2}$ 5627-5631. 
Ewan KB, Oketch-Rabah HA, Ravani SA, Shyamala G, Moses HL \& Barcellos-Hoff MH 2005 Proliferation of estrogen receptor-alpha-positive mammary epithelial cells is restrained by transforming growth factor-betal in adult mice. American Journal of Pathology 167 409-417.

Forster C, Makela S, Warri A, Kietz S, Becker D, Hultenby K, Warner M \& Gustafsson JA 2002 Involvement of estrogen receptor beta in terminal differentiation of mammary gland epithelium. PNAS 99 15578-15583.

Frech MS, Halama ED, Tilli MT, Singh B, Gunther EJ, Chodosh LA, Flaws JA \& Furth PA 2005 Deregulated estrogen receptor-alpha expression in mammary epithelial cells of transgenic mice results in the development of ductal carcinoma in situ. Cancer Research 65 681-685.

Freed E, Lacey KR, Huie P, Lyapina SA, Deshaies RJ, Stearns T \& Jackson PK 1999 Components of an SCF ubiquitin ligase localize to the centrosome and regulate the centrosome duplication cycle. Genes Development 13 2242-2257.

Fukuchi M, Imamura T, Chiba T, Ebisawa T, Kawabata M, Tanaka K \& Miyazono K 2001 Ligand-dependent degradation of Smad3 by a ubiquitin ligase complex of $\mathrm{ROC} 1$ and associated proteins. Molecular Biology of the Cell 12 1431-1443.

Furuta S, Jiang X, Gu B, Cheng E, Chen PL \& Lee WH 2005 Depletion of BRCA1 impairs differentiation but enhances proliferation of mammary epithelial cells. PNAS $\mathbf{1 0 2}$ 9176-9181.

Ge R, Rajeev V, Subramanian G, Reiss KA, Liu D, Higgins L, Joly A, Dugar S, Chakravarty J \& Henson M 2004 Selective inhibitors of type I receptor kinase block cellular transforming growth factor-beta signaling. Biochemical Pharmacology 68 41-50.

Gerwin BI, Spillare E, Forrester K, Lehman TA, Kispert J, Welsh JA, Pfeifer AM, Lechner JF, Baker SJ, Vogelstein B et al. 1992 Mutant p53 can induce tumorigenic conversion of human bronchial epithelial cells and reduce their responsiveness to a negative growth factor, transforming growth factor beta 1. PNAS $892759-2763$.

Glick AB, Weinberg WC, Wu IH, Quan W \& Yuspa SH 1996 Transforming growth factor beta 1 suppresses genomic instability independent of a G1 arrest, p53, and Rb. Cancer Research 56 3645-3650.

Glick A, Popescu N, Alexander V, Ueno H, Bottinger E \& Yuspa SH 1999 Defects in transforming growth factor-beta signaling cooperate with a Ras oncogene to cause rapid aneuploidy and malignant transformation of mouse keratinocytes. PNAS 96 14949-14954.

Godden J, Porteous C, George WD \& Kerr DJ 1993 Bioassay of transforming growth factor- $\beta$ activity in acidic protein extracts from primary breast cancer specimens. Anticancer Research 13 427-431.

Godkin JD \& Dore JJ 1998 Transforming growth factor beta and the endometrium. Reviews in Reproduction 3 1-6.

Goepfert TM, McCarthy M, Kittrell FS, Stephens C, Ullrich RL, Brinkley BR \& Medina D 2000 Progesterone facilitates chromosome instability (aneuploidy) in p53 null normal mammary epithelial cells. FASEB Journal 14 2221-2229.

Gofman JW 1990 Radiation-Induced Cancer from Low-Dose Exposure: An Independent Analysis, p1-480, 1st Edn, Ed. C T Berkeley, Committee for Nuclear Responsibility Inc.

Gold LI, Saxena B, Mittal KR, Marmor M, Goswami S, Nactigal L, Korc M \& Demopoulos RI 1994 Increased expression of transforming growth factor beta isoforms and basic fibroblast growth factor in complex hyperplasia and adenocarcinoma of the endometrium: evidence for paracrine and autocrine action. Cancer Research 54 2347-2358.

Gorsch SM, Memoli VA, Stukel TA, Gold LI \& Arrick BA 1992 Immunohistochemical staining for transforming growth factor $\beta 1$ associates with disease progression in human breast cancer. Cancer Research 52 6949-6952.

Gotzmann J, Mikula M, Eger A, Schulte-Hermann R, Foisner R, Beug H \& Mikulits W 2004 Molecular aspects of epithelial cell plasticity: implications for local tumor invasion and metastasis. Mutation Research 566 9-20.

Grunert S, Jechlinger M \& Beug H 2003 Diverse cellular and molecular mechanisms contribute to epithelial plasticity and metastasis. Nature Reviews in Molecular and Cellular Biology 4 657-665.

Guo Y \& Kyprianou N 1998 Over-expression of transforming growth factor (TGF) betal type II receptor restores TGF-beta1 sensitivity and signaling in human prostate cancer cells. Cell Growth and Differentiation 9 185-193.

Guo Y, Jacobs SC \& Kyprianou N 1997 Down-regulation of protein and mRNA expression for transforming growth factor-beta (TGF-beta1) type I and type II receptors in human prostate cancer. International Journal of Cancer 71 573-579.

Halder SK, Beauchamp RD \& Datta PK 2005 Smad7 induces tumorigenicity by blocking TGF-beta-induced growth inhibition and apoptosis. Experimental Cell Research $\mathbf{3 0 7}$ 231-246.

Hamel FG, Fawcett J, Bennett RG \& Duckworth WC 2004 Control of proteolysis: hormones, nutrients, and the changing role of the proteasome. Current Opinion in Clinical Nutrition and Metabolic Care 7 255-258.

Hashizume R, Fukuda M, Maeda I, Nishikawa H, Oyake D, Yabuki Y, Ogata H \& Ohta T 2001 The RING heterodimer BRCA1-BARD1 is a ubiquitin ligase inactivated by a breast cancer-derived mutation. Journal of Biological Chemistry 276 14537-14540.

Helms MW, Packeisen J, August C, Schittek B, Boecker W, Brandt BH \& Buerger H 2005 First evidence supporting a potential role for the BMP/SMAD pathway in the progression of oestrogen receptor-positive breast cancer. Journal of Pathology 206 366-376.

Herpin A, Lelong C \& Favrel P 2004 Transforming growth factor-beta-related proteins: an ancestral and widespread superfamily of cytokines in metazoans. Developments in Comparative Immunology 28 461-485. 
Hirao A, Cheung A, Duncan G, Girard PM, Elia AJ, Wakeham A, Okada H, Sarkissian T, Wong JA, Sakai T et al. 2002 Chk2 is a tumor suppressor that regulates apoptosis in both an ataxia telangiectasia mutated (ATM)-dependent and an ATM-independent manner. Molecular and Cellular Biology 22 6521-6532.

Hojo M, Morimoto T, Maluccio M, Asano T, Morimoto K, Lagman M, Shimbo T \& Suthanthiran M 1999 Cyclosporine induces cancer progression by a cellautonomous mechanism. Nature 397 530-534.

Hsu LC \& White RL 1998 BRCA1 is associated with the centrosome during mitosis. PNAS 95 12983-12988.

Hsu LC, Doan TP \& White RL 2001 Identification of a gamma-tubulin-binding domain in BRCA1. Cancer Research 61 7713-7718.

Javelaud D \& Mauviel A 2004 Mammalian transforming growth factor-betas: Smad signaling and physiopathological roles. International Journal of Biochemistry and Cell Biology 36 1161-1165.

Jerry DJ, Kuperwasser C, Downing SR, Pinkas J, He C, Dickinson E, Marconi S \& Naber SP 1998 Delayed involution of the mammary epithelium in BALB/c-p53null mice. Oncogene 17 2305-2312.

Jhappan C, Geiser AG, Kordon EC, Bagheri D, Hennighausen L, Roberts AB, Smith GH \& Merlino G 1993 Targeting expression of a transforming growth factor $\beta 1$ transgene to the pregnant mammary gland inhibits alveolar development and lactation. EMBO Journal 12 1835-1845.

Kang Y, Chen CR \& Massague J 2003 A self-enabling TGFbeta response coupled to stress signaling: Smad engages stress response factor ATF3 for Id 1 repression in epithelial cells. Molecular Cell 11 915-926.

Kawamura K, Fujikawa-Yamamoto K, Ozaki M, Iwabuchi K, Nakashima H, Domiki C, Morita N, Inoue M, Tokunaga K, Shiba N et al. 2004 Centrosome hyperamplification and chromosomal damage after exposure to radiation. Oncology 67 460-470.

Kennedy RD, Quinn JE, Mullan PB, Johnston PG \& Harkin DP 2004 The role of BRCA1 in the cellular response to chemotherapy. Journal of the National Cancer Institute 96 1659-1668.

Khan SA, Rogers MA, Obando JA \& Tamsen A 1994 Estrogen receptor expression of benign breast epithelium and its association with breast cancer. Cancer Research $\mathbf{5 4}$ 993-997.

Khosravi R, Maya R, Gottlieb T, Oren M, Shiloh Y \& Shkedy D 1999 Rapid ATM-dependent phosphorylation of MDM2 precedes p53 accumulation in response to DNA damage. PNAS 96 14973-14977.

Kim IY, Ahn HJ, Zelner DJ, Park L, Sensibar JA \& Lee C 1996 Expression and localization of transforming growth factor-beta receptors type I and type II in the rat ventral prostate during regression. Molecular Endocrinology 10 107-115.

Kim SJ, Im YH, Markowitz SD \& Bang YJ 2000 Molecular mechanisms of inactivation of TGF-beta receptors during carcinogenesis. Cytokine Growth Factor Reviews 11 159-168.
Kleeff J, Ishiwata T, Maruyama H, Friess H, Truong P, Buchler MW, Falb D \& Korc M 1999 The TGF-beta signaling inhibitor Smad7 enhances tumorigenicity in pancreatic cancer. Oncogene 18 5363-5372.

Kolb M, Margetts PJ, Sime PJ \& Gauldie J 2001

Proteoglycans decorin and biglycan differentially modulate TGF-beta-mediated fibrotic responses in the lung. American Journal of Physiology and Lung Cell Molecular Physiology 280 L1327-L1334.

Koli KM, Ramsey TT, Ko Y, Dugger TC, Brattain MG \& Arteaga CL 1997 Blockade of transforming growth factor-beta signaling does not abrogate antiestrogeninduced growth inhibition of human breast carcinoma cells. Journal of Biological Chemistry 272 8296-8302.

Korchynskyi O, Landstrom M, Stoika R, Funa K, Heldin CH, ten Dijke P \& Souchelnytskyi S 1999 Expression of Smad proteins in human colorectal cancer. International Journal of Cancer 82 197-202.

Kordon EC, McKnight RA, Jhappan C, Hennighausen L, Merlino G \& Smith GH 1995 Ectopic TGF beta 1 expression in the secretory mammary epithelium induces early senescence of the epithelial stem cell population. Developmental Biology 168 47-61.

Kowanetz M, Valcourt U, Bergstrom R, Heldin CH \& Moustakas A 2004 Id 2 and Id3 define the potency of cell proliferation and differentiation responses to transforming growth factor beta and bone morphogenetic protein. Molecular and Cellular Biology 24 4241-4254.

Kuratomi G, Komuro A, Goto K, Shinozaki M, Miyazawa K, Miyazono K \& Imamura T 2005 NEDD4-2 (neural precursor cell expressed, developmentally down-regulated 4-2) negatively regulates TGF-beta (transforming growth factor-beta) signalling by inducing ubiquitin-mediated degradation of Smad2 and TGF-beta type I receptor. Biochemical Journal 386 461-470.

Kyprianou N 1999 Activation of TGF-beta signalling in human prostate cancer cells suppresses tumorigenicity via deregulation of cell cycle progression and induction of caspase-1-mediated apoptosis: significance in prostate tumorigenesis. Prostate Cancer Prostatic Disease 2 S18.

Kyprianou N \& Isaacs JT 1989 Expression of transforming growth factor $\beta$ in the rat ventral prostate during castration-induced programmed cell death. Molecular Endocrinology 3 1515-1522.

Kyprianou N, Alexander RB \& Isaacs JT 1991 Activation of programmed cell death by recombinant human tumor necrosis factor plus topoisomerase II-targeted drugs in L929 tumor cells. Journal of the National Cancer Institute 83 346-350.

Labhart P, Karmakar S, Salicru EM, Egan BS, Alexiadis V, O'Malley BW \& Smith CL 2005 Identification of target genes in breast cancer cells directly regulated by the SRC-3/AIB1 coactivator. PNAS 102 1339-1344.

Laios I, Journe F, Nonclercq D, Vidal DS, Toillon RA, Laurent G \& Leclercq G 2005 Role of the proteasome in the regulation of estrogen receptor alpha turnover and function in MCF-7 breast carcinoma cells. Journal of Steroid Biochemistry and Molecular Biology 94 347-359. 
Lallemand F, Seo SR, Ferrand N, Pessah M, L'Hoste S, Rawadi G, Romain-Romain S, Camonis J \& Atfi A 2005 AIP4 restricts TGF-beta signaling through a ubiquitination-independent mechanism. Journal of Biological Chemistry $28027645-27653$.

Landesman Y, Bringold F, Milne DD \& Meek DW 1997 Modifications of $\mathrm{p} 53$ protein and accumulation of $\mathrm{p} 21$ and gadd45 mRNA in TGF-beta 1 growth inhibited cells. Cellular Signalling 9 291-298.

Lawson JS, Field AS, Champion S, Tran D, Ishikura H \& Trichopoulos D 1999 Low oestrogen receptor alpha expression in normal breast tissue underlies low breast cancer incidence in Japan. Lancet 354 1787-1788.

Lawson JS, Field AS, Tran DD, Killeen J, Maskarenic G, Ishikura H \& Trichopoulos D 2002 Breast cancer incidence and estrogen receptor alpha in normal mammary tissue - an epidemiologic study among Japanese women in Japan and Hawaii. International Journal of Cancer 97 685-687.

Lazzereschi D, Nardi F, Turco A, Ottini L, D’Amico C, Mariani-Costantini R, Gulino A \& Coppa A 2005 A complex pattern of mutations and abnormal splicing of Smad4 is present in thyroid tumours. Oncogene $\mathbf{2 4}$ 5344-5534.

Lee YI, Kwon YJ \& Joo CK 2004 Integrin-linked kinase function is required for transforming growth factor beta-mediated epithelial to mesenchymal transition. Biochemical and Biophysical Research Communications 316 997-1001.

Li Y, Yang J, Dai C, Wu C \& Liu Y 2003 Role for integrinlinked kinase in mediating tubular epithelial to mesenchymal transition and renal interstitial fibrogenesis. Journal of Clinical Investigation 112 503-516.

Li JJ, Weroha SJ, Lingle WL, Papa D, Salisbury JL \& Li SA 2004 Estrogen mediates Aurora-A overexpression, centrosome amplification, chromosomal instability, and breast cancer in female ACI rats. PNAS 101 18123-18128.

Liang M, Melchior F, Feng XH \& Lin X 2004 Regulation of Smad4 sumoylation and transforming growth factor-beta signaling by protein inhibitor of activated STAT1. Journal of Biological Chemistry 279 22857-22865.

Liu G, Schwartz JA \& Brooks SC 1999 p53 down-regulates ER-responsive genes by interfering with the binding of ER to ERE. Biochemical and Biophysical Research Communications 264 359-364.

Liu G, Schwartz JA \& Brooks SC 2000 Estrogen receptor protects p53 from deactivation by human double minute-2. Cancer Research 60 1810-1814.

Long J, Matsuura I, He D, Wang G, Shuai K \& Liu F 2003 Repression of Smad transcriptional activity by PIAS $\gamma$, an inhibitor of activated STAT. PNAS 100 9791-9796.

Lopez-Casillas F, Wrana JL \& Massague J 1993 Betaglycan presents ligand to the TGF $\beta$ signaling receptor. Cell $\mathbf{7 3}$ 1435-1444.

Ludbrook SB, Barry ST, Delves CJ \& Horgan CM 2003 The integrin alphavbeta 3 is a receptor for the latencyassociated peptides of transforming growth factors betal and beta3. Biochemical Journal 369 311-318.
McBride WH, Iwamoto KS, Syljuasen R, Pervan M \& Pajonk F 2003 The role of the ubiquitin/proteasome system in cellular responses to radiation. Oncogene 22 5755-5773.

McCune BK, Mullin BR, Flanders KC, Jaffurs WJ, Mullen LT \& Sporn MB 1992 Localization of transforming growth factor- $\beta$ isotypes in lesions of the human breast. Human Pathology 23 13-20.

Maehara Y, Kakeji Y, Kabashima A, Emi Y, Watanabe A, Akazawa K, Baba H, Kohnoe S \& Sugimachi K 1999 Role of transforming growth factor-beta 1 in invasion and metastasis in gastric carcinoma. Journal of Clinical Oncology 17 607-614.

Mahara K, Kato J, Terui T, Takimoto R, Horimoto M, Murakami T, Mogi Y, Watanabe N, Kohgo Y \& Niitsu Y 1994 Transforming growth factor beta 1 secreted from scirrhous gastric cancer cells is associated with excesss collagen deposition in the tissue. British Journal of Cancer $69777-783$.

Marshburn PB, Arici AM \& Casey ML 1994 Expression of transforming growth factor-beta 1 messenger ribonucleic acid and the modulation of deoxyribonucleic acid synthesis by transforming growth factor-beta 1 in human endometrial cells. American Journal of Obstetics and Gynecology 170 1152-1158.

Martikainen P, Kyprianou N \& Isaacs JT 1990 Effect of transforming growth factor- $\beta 1$ on proliferation and death of rat prostatic cells. Endocrinology 127 2963-2968.

Massague J \& Chen YG 2000 Controlling TGF-beta signaling. Genes and Development 14 627-644.

Masszi A, Fan L, Rosivall L, McCulloch CA, Rotstein OD, Mucsi I \& Kapus A 2004 Integrity of cell-cell contacts is a critical regulator of TGF-beta 1-induced epithelial-tomyofibroblast transition: role for beta-catenin. American Journal of Pathology 165 1955-1967.

Matsuda T, Yamamoto T, Muraguchi A \& Saatcioglu F 2001 Cross-talk between transforming growth factor-beta and estrogen receptor signaling through Smad3. Journal of Biological Chemistry 276 42908-42914.

Medina D \& Kittrell FS 2003 p53 function is required for hormone-mediated protection of mouse mammary tumorigenesis. Cancer Research 63 6140-6143.

Menke A, Yamaguchi H, Gress TM \& Adler G 1997 Extracellular matrix is reduced by inhibition of transforming growth factor beta 1 in pancreatitis in the rat. Gastroenterology 113 295-303.

Merryman JI, Neilsen N \& Stanton DD 1998 Transforming growth factor-beta enhances the ultraviolet-mediated stress response in p53-/- keratinocytes. International Journal of Oncology 13 781-789.

Moren A, Imamura T, Miyazono K, Heldin CH \& Moustakas A 2005 Degradation of the tumor suppressor Smad4 by WW and HECT domain ubiquitin ligases. Journal of Biological Chemistry 280 22115-22123.

Muraoka RS, Dumont N, Ritter CA, Dugger TC, Brantley DM, Chen J, Easterly E, Roebuck LR, Ryan S, Gotwals PJ et al. 2002 Blockade of TGF-beta inhibits mammary tumor cell viability, migration, and metastases. Journal of Clinical Investigations 109 1551-1559. 
Muraoka-Cook RS, Kurokawa H, Koh Y, Forbes JT, Roebuck LR, Barcellos-Hoff MH, Moody SE, Chodosh LA \& Arteaga CL 2004 Conditional over-expression of active transforming growth factor $\beta$ accelerates metastases of transgenic mammary tumors. Cancer Research 64 9002-9011.

Murray PA, Barrett-Lee P, Travers M, Luqmani Y, Powles T \& Coombes RC 1993 The prognostic significance of transforming growth factors in human breast cancer. British Journal of Cancer 67 1408-1412.

Nakayama K, Nagahama H, Minamishima YA, Matsumoto M, Nakamichi I, Kitagawa K, Shirane M, Tsunematsu R, Tsukiyama T, Ishida N et al. 2000 Targeted disruption of Skp2 results in accumulation of cyclin E and p27(Kip1), polyploidy and centrosome overduplication. EMBO Journal 19 2069-2081.

Nicolussi A, D'Inzeo S, Santulli M, Colletta G \& Coppa A 2003 TGF-beta control of rat thyroid follicular cells differentiation. Molecular and Cellular Endocrinology 207 $1-11$.

Nishioka A, Ogawa Y, Mima T, Jin YJ, Sonobe H, Kariya S, Kubota K, Yoshida S \& Ueno H 2004 Histopathologic amelioration of fibroproliferative change in rat irradiated lung using soluble transforming growth factor-beta (TGF-beta) receptor mediated by adenoviral vector. International Journal of Radiation Oncology and Biological Physics 58 1235-1241.

Ohashi N, Yamamoto T, Uchida C, Togawa A, Fukasawa H, Fujigaki Y, Suzuki S, Kitagawa K, Hattori T, Oda T et al. 2005 Transcriptional induction of Smurf2 ubiquitin ligase by TGF-beta. FEBS Letters 579 2557-2563.

Ohshima T \& Shimotohno K 2003 Transforming growth factor-beta-mediated signaling via the p38 MAP kinase pathway activates Smad-dependent transcription through SUMO-1 modification of Smad4. Journal of Biological Chemistry 278 50833-50842.

Ozdamar B, Bose R, Barrios-Rodiles M, Wang HR, Zhang Y \& Wrana JL 2005 Regulation of the polarity protein Par6 by TGFbeta receptors controls epithelial cell plasticity. Science 307 1603-1609.

Parekh TV, Gama P, Wen X, Demopoulos R, Munger JS, Carcangiu M-L, Reiss M \& Gold LI 2002 Transforming growth factor beta signaling is disabled early in human endometrial carcinogenesis concomitant with loss of growth inhibition. Cancer Research 62 2778-2790.

Pierce DFJ, Johnson MD, Matsui Y, Robinson SD, Gold LI, Purchio AF, Daniel CW, Hogan BLM \& Moses HL 1993 Inhibition of mammary duct development but not alveolar outgrowth during pregnancy in transgenic mice expressing active TGF- $\beta 1$. Genes and Development 7 2308-2317.

Piestrzeniewicz-Ulanska D, Brys M, Semczuk A, Jakowicki JA \& Krajewska WM 2002 Expression of TGF-beta type I and II receptors in normal and cancerous human endometrium. Cancer Letters 186 231-239.

Piestrzeniewicz-Ulanska D, Brys M, Semczuk A, Jakowicki JA \& Krajewska WM 2003 Expression and intracellular localization of Smad proteins in human endometrial cancer. Oncology Reports 10 1539-1544.

Piestrzeniewicz-Ulanska D, Brys M, Semczuk A, Rechberger T, Jakowicki JA \& Krajewska WM 2004 TGF-beta signaling is disrupted in endometrioid-type endometrial carcinomas. Gynecology and Oncology 95 173-180.

Pihan GA, Purohit A, Wallace J, Knecht H, Woda B, Quesenberry P \& Doxsey SJ 1998 Centrosome defects and genetic instability in malignant tumors. Cancer Research 58 3974-3985.

Pihan GA, Purohit A, Wallace J, Malhotra R, Liotta LA \& Doxsey SJ 2001 Centrosome defects can account for cellular and genetic changes that characterize prostate cancer progression. Cancer Research 61 2212-2219.

Pihan GA, Wallace J, Zhou Y \& Doxsey SJ 2003 Centrosome abnormalities and chromosome instability occur together in pre-invasive carcinomas. Cancer Research 63 1398-1404.

Prunier C \& Howe PH 2005 Disabled-2 (Dab2) is required for transforming growth factor beta-induced epithelial to mesenchymal transition (EMT). Journal of Biological Chemistry 280 17540-17548.

Rabbani ZN, Anscher MS, Zhang X, Chen L, Samulski TV, Li CY \& Vujaskovic Z 2003a Soluble TGFbeta type II receptor gene therapy ameliorates acute radiation-induced pulmonary injury in rats. International Journal of Radiation, Oncology, Biology and Physics 57 563-572.

Rabbani ZN, Anscher MS, Golson ML, Chen L, Archer E, Folz RJ, Samulski TV, Dewhirst MW \& Vujaskovic Z $2003 b$ Overexpression of extracellular superoxide dismutase reduces severity of radiation-induced lung toxicity through down-regulation of the TGF-beta signal transduction pathway. International Journal of Radiation, Oncology, Biology and Physics 57 S158-S159.

Reiss M, Vellucci VF \& Zhou ZL 1993 Mutant p53 tumor suppressor gene causes resistance to transforming growth factor beta 1 in murine keratinocytes. Cancer Research $\mathbf{5 3}$ 899-904.

Reya T, Morrison SJ, Clarke MF \& Weissman IL 2001 Stem cells, cancer, and cancer stem cells. Nature $\mathbf{4 1 4}$ 105-111.

Rifkin D 2005 Latent transforming growth factor- $\beta$ (TGF- $\beta$ ) binding proteins: orchestrators of TGF- $\beta$ availablity. Journal of Biological Chemistry 280 7409-7412.

Roberts AB \& Wakefield LM 2003 The two faces of transforming growth factor beta in carcinogenesis. PNAS $1008621-8623$.

Roberts AB, Anzano MA, Lamb LC, Smith JM \& Sporn MB 1981 New class of transforming growth factors potentiated by epidermal growth factor: isolation from non-neoplastic tissue. PNAS 78 5339-5343.

Robinson SD, Silberstein GB, Roberts AB, Flanders KC \& Daniel CD 1991 Regulated expression and growth inhibitory effects of transforming growth factor- $\beta$ isoforms in mouse mammary gland development. Development 113 $867-878$. 
Rosner B, Colditz GA \& Willett WC 1994 Reproductive risk factors in a prospective study of breast cancer: the Nurses' Health Study. American Journal of Epidemiology 139 819-835.

Russo J, Ao X, Grill C \& Russo IH 1999 Pattern of distribution of cells positive for estrogen receptor alpha and progesterone receptor in relation to proliferating cells in the mammary gland. Breast Cancer Research and Treatment 53 217-227.

Sakakura T 1983 Epithelial-mesenchymal interactions in mammary gland development and its perturbation in relation to tumorigenesis. In Understanding Breast Cancer, pp 261-284. Eds MA Rich, JC Hager \& P Furmakski. New York and Basel: Marcel Dekker, Inc.

Salisbury JL, D'Assoro AB \& Lingle WL 2004 Centrosome amplification and the origin of chromosomal instability in breast cancer. Journal of Mammary Gland Biology and Neoplasia 9 275-283.

Salm SN, Burger PE, Coetzee S, Goto K, Moscatelli D \& Wilson EL 2005 TGF-beta maintains dormancy of prostatic stem cells in the proximal region of ducts. Journal of Cell Biology 170 81-90.

Sato C, Kuriyama R \& Nishizawa K 1983 Microtubuleorganizing centers abnormal in number, structure, and nucleating activity in $\mathrm{x}$-irradiated mammalian cells. Journal of Cell Biology 96 776-782.

Sato N, Mizumoto K, Nakamura M \& Tanaka M 2000 Radiation-induced centrosome overduplication and multiple mitotic spindles in human tumor cells. Experimental Cell Research 255 321-326.

Satterwhite DJ, Matsunami N \& White RL 2000 TGF-beta1 inhibits BRCA1 expression through a pathway that requires pRb. Biochemical and Biophysical Research Communications 276 686-692.

Schier AF 2003 Nodal signaling in vertebrate development. Annual Reviews in Cell Development Biology 19 589-621.

Schneeweiss A, Sinn HP, Ehemann V, Khbeis T, Neben K, Krause U, Ho AD, Bastert G \& Kramer A 2003 Centrosomal aberrations in primary invasive breast cancer are associated with nodal status and hormone receptor expression. International Journal of Cancer 107 346-352.

Schultz-Cherry S, Ribeiro S, Gentry L \& Murphy-Ullrich J 1994 Thrombospondin binds and activates the small and large forms of latent transforming growth factor-beta in a chemically defined system. Journal of Biological Chemistry $26926775-26782$.

Schultze-Mosgau S, Blaese MA, Grabenbauer G, Wehrhan F, Kopp J, Amann K, Rodemann HP \& Rodel F 2004 Smad3 and Smad-7 expression following anti-transforming growth factor beta 1 (TGF $\beta 1$ )-treatment in irradiated rat tissue. Radiotherapy and Oncology 70 249-259.

Sengupta S \& Harris CC 2005 p53: traffic cop at the crossroads of DNA repair and recombination. Nature Reviews in Molecular and Cellular Biology 6 44-55.

Seoane J 2004 p21(WAF1/CIP1) at the switch between the anti-oncogenic and oncogenic faces of TGFbeta. Cancer Biology and Therapy 3 226-227.
Seoane J, Le HV \& Massague J 2002 Myc suppression of the p21(Cip1) Cdk inhibitor influences the outcome of the p53 response to DNA damage. Nature 419 729-734.

Sheng Z, Sun W, Smith E, Cohen C \& Xu XX 2000 Restoration of positioning control following Disabled-2 expression in ovarian and breast tumor cells. Oncogene 19 4847-4854.

Shi Y \& Massague J 2003 Mechanisms of TGF-beta signaling from cell membrane to the nucleus. Cell 113 685-700.

Shimizu K, Bourillot PY, Nielsen SJ, Zorn AM \& Gurdon JB 2001 Swift is a novel BRCT domain coactivator of Smad2 in transforming growth factor beta signaling. Molecular and Cellular Biology 21 3901-3912.

Shoker BS, Jarvis C, Clarke RB, Anderson E, Hewlett J, Davies MP, Sibson DR \& Sloane JP 1999 Estrogen receptor-positive proliferating cells in the normal and precancerous breast. American Journal of Pathology 155 1811-1815.

Shono M, Sato N, Mizumoto K, Minamishima YA, Nakamura M, Maehara N, Urashima T, Saimura M, Qian L, Nishio S et al. 2001 Effect of serum depletion on centrosome overduplication and death of human pancreatic cancer cells after exposure to radiation. Cancer Letters 170 81-89.

Shooner C, Caron PL, Frechette-Frigon G, Leblanc V, Dery MC \& Asselin E 2005 TGF-beta expression during rat pregnancy and activity on decidual cell survival. Reproduction Biology and Endocrinology 320.

Siegel PM \& Massague J 2003 Cytostatic and apoptotic actions of TGF-beta in homeostasis and cancer. Nature Reviews in Cancer 3 807-821.

Smith GH 1996 TGF- $\beta$ and functional differentiation. Journal of the Mammary Gland Biology and Neoplasia 1 343-352.

Somasundaram K, MacLachlan TK, Burns TF, Sgagias M, Cowan KH, Weber BL \& el-Deiry WS 1999 BRCA1 signals ARF-dependent stabilization and coactivation of p53. Oncogene 18 6605-6614.

Starita LM, Machida Y, Sankaran S, Elias JE, Griffin K, Schlegel BP, Gygi SP \& Parvin JD 2004 BRCA1-dependent ubiquitination of gamma-tubulin regulates centrosome number. Molecular and Cellular Biology 24 8457-8466.

Steiner MS, Zhou ZZ, Tonb DC \& Barrack ER 1994 Expression of transforming growth factor-beta 1 in prostate cancer. Endocrinology 135 2240-2247.

Strange R, Li F, Saurer S, Burkhardt A \& Friis RR 1992 Apoptotic cell death and tissue remodeling during mouse mammary gland involution. Development 115 49-58.

Suen CS, Berrodin TJ, Mastroeni R, Cheskis BJ, Lyttle CR \& Frail DE 1998 A transcriptional coactivator, steroid receptor coactivator-3, selectively augments steroid receptor transcriptional activity. Journal of Biological Chemistry $27327645-27653$.

Takebayashi-Suzuki K, Funami J, Tokumori D, Saito A, Watabe T, Miyazono K, Kanda A \& Suzuki A 2003 Interplay between the tumor suppressor p53 and TGF $\beta$ signaling shapes embryonic body axes in Xenopus. Development 130 3929-3939. 
Tarapore P \& Fukasawa K 2002 Loss of p53 and centrosome hyperamplification. Oncogene 21 6234-6240.

Thiery JP 2002 Epithelial-mesenchymal transitions in tumour progression. Nature Reviews in Cancer 2 442-454.

Thiery JP 2003 Epithelial-mesenchymal transitions in development and pathologies. Current Opinion in Cell Biology 15 740-746.

Thompson AM, Kerr DJ \& Steel CM 1991 Transforming growth factor beta 1 is implicated in the failure of tamoxifen therapy in human breast cancer. British Journal of Cancer 63 609-614.

Travers MT, Barrett-Lee PJ, Berger U, Luqmani YA, Gazet JC, Powles TJ \& Coombes RC 1988 Growth factor expression in normal, benign, and malignant breast tissue. British Medical Journal 296 1621-1624.

Tsujimura A, Koikawa Y, Salm S, Takao T, Coetzee S, Moscatelli D, Shapiro E, Lepor H, Sun TT \& Wilson EL 2002 Proximal location of mouse prostate epithelial stem cells: a model of prostatic homeostasis. Journal of Cell Biology 157 1257-1265.

Untergasser G, Gander R, Lilg C, Lepperdinger G, Plas E \& Berger P 2005 Profiling molecular targets of TGF-beta1 in prostate fibroblast-to-myofibroblast transdifferentiation. Mechanics of Ageing Development 126 59-69.

Wakefield 1, Colletta AA, McCune BK \& Sporn MB 1991 Roles for transforming growth factor- $\beta$ in the genesis, prevention and treatment of breast cancer. In Genes, Oncogens, and Hormones: Advances in Cellular and Molecular Biology of Breast Cancer, pp 97-136. Eds RB Dickson \& ME Lippman. Boston: Kluwer Academic Publishers.

Wang RA \& Zhao GQ 1999 Transforming growth factor beta signal transducer Smad2 is expressed in mouse meiotic germ cells, Sertoli cells, and Leydig cells during spermatogenesis. Biology of Reproduction 61 999-1004.

Wigley WC, Fabunmi RP, Lee MG, Marino CR, Muallem S, DeMartino GN \& Thomas PJ 1999 Dynamic association of proteasomal machinery with the centrosome. Journal of Cell Biology 145 481-490.

Wrana JL, Attisano L, Wieser R, Ventura F \& Massague J 1994 Mechanism of activation of the TGF-beta receptor. Nature 370 341-347.

Wu L, Wu Y, Gathings B, Wan M, Li X, Grizzle W, Liu Z, Lu C, Mao Z \& Cao X 2003 Smad4 as a transcription corepressor for estrogen receptor alpha. Journal of Biological Chemistry 278 15192-15200.
Wyllie FS, Dawson T, Bond JA, Goretzki P, Game S, Prime S \& Wynford-Thomas D 1991 Correlated abnormalities of transforming growth factor-beta 1 response and p53 expression in thyroid epithelial cell transformation. Molecular and Cellular Endocrinology 76 13-21.

Xavier S, Piek E, Fujii M, Javelaud D, Mauviel A, Flanders KC, Samuni AM, Felici A, Reiss M, Yarkoni S et al. 2004 Amelioration of radiation-induced fibrosis: inhibition of transforming growth factor- $\beta$ signaling by halofuginone. Journal of Biological Chemistry 279 15167-15176.

Xie W, Mertens JC, Reiss DJ, Rimm DL, Camp RL, Haffty BG \& Reiss M 2002 Alterations of Smad signaling in human breast carcinoma are associated with poor outcome: a tissue microarray study. Cancer Research 62 497-505.

Yamamoto T, Saatcioglu F \& Matsuda T 2002 Cross-talk between bone morphogenic proteins and estrogen receptor signaling. Endocrinology 143 2635-2642.

Yingling JM, Blanchard KL \& Sawyer JS 2004 Development of TGF- $\beta$ signalling inhibitors for cancer therapy. Nature Reviews Drug Discovery 3 1011-1022.

Yoon HS, Ghaleb AM, Nandan MO, Hisamuddin IM, Dalton WB \& Yang VW 2005 Kruppel-like factor 4 prevents centrosome amplification following gamma-irradiationinduced DNA damage. Oncogene 24 4017-4025.

Young GD \& Murphy-Ullrich JE 2004 Molecular interactions that confer latency to transforming growth factor-beta (TGF-beta). Journal of Biological Chemistry M405658200.

Yue J \& Mulder KM 2001 Transforming growth factor-beta signal transduction in epithelial cells. Pharmacological Therapy 91 1-34.

Zeng R, Li X \& Gorodeski GI 2004 Estrogen abrogates transcervical tight junctional resistance by acceleration of occludin modulation. Journal of Clinical Endocrinology and Metabolism 89 5145-5155.

Zhu H, Kavsak P, Abdollah S, Wrana JL \& Thomsen GH 1999 A SMAD ubiquitin ligase targets the BMP pathway and affects embryonic pattern formation. Nature $\mathbf{4 0 0}$ 687-693.

Ziv E, Cauley J, Morin PA, Saiz R \& Browner WS 2001 Association between the $\mathrm{T} 29 \rightarrow \mathrm{C}$ polymorphism in the transforming growth factor beta 1 gene and breast cancer among elderly white women: the study of osteoporotic fractures. Journal of the American Medical Association 13 2859-2863. 